Article

\title{
Application of Liquid Hydrogen Carriers in Hydrogen Steelmaking
}

\author{
Joakim Andersson (D)
}

check for

updates

Citation: Andersson, J. Application of Liquid Hydrogen Carriers in Hydrogen Steelmaking. Energies 2021, 14, 1392. https://doi.org/10.3390/ en14051392

Academic Editor: Muhammad Aziz

Received: 9 February 2021

Accepted: 25 February 2021

Published: 3 March 2021

Publisher's Note: MDPI stays neutral with regard to jurisdictional claims in published maps and institutional affiliations.

Copyright: (C) 2021 by the author. Licensee MDPI, Basel, Switzerland. This article is an open access article distributed under the terms and conditions of the Creative Commons Attribution (CC BY) license (https:/ / creativecommons.org/licenses/by/ $4.0 /)$.
Department of Chemical Engineering, Division of Energy Processes, KTH Royal Institute of Technology, SE-10044 Stockholm, Sweden; joakim9@kth.se

Abstract: Steelmaking is responsible for approximately one third of total industrial carbon dioxide $\left(\mathrm{CO}_{2}\right)$ emissions. Hydrogen $\left(\mathrm{H}_{2}\right)$ direct reduction $(\mathrm{H}-\mathrm{DR})$ may be a feasible route towards the decarbonization of primary steelmaking if $\mathrm{H}_{2}$ is produced via electrolysis using fossil-free electricity. However, electrolysis is an electricity-intensive process. Therefore, it is preferable that $\mathrm{H}_{2}$ is predominantly produced during times of low electricity prices, which is enabled by the storage of $\mathrm{H}_{2}$. This work compares the integration of $\mathrm{H}_{2}$ storage in four liquid carriers, methanol $(\mathrm{MeOH})$ formic acid (FA), ammonia $\left(\mathrm{NH}_{3}\right)$ and perhydro-dibenzyltoluene (H18-DBT), in H-DR processes. In contrast to conventional $\mathrm{H}_{2}$ storage methods, these carriers allow for $\mathrm{H}_{2}$ storage in liquid form at moderate overpressures, reducing the storage capacity cost. The main downside to liquid $\mathrm{H}_{2}$ carriers is that thermochemical processes are necessary for both the storage and release processes, often with significant investment and operational costs. The carriers are compared using thermodynamic and economic data to estimate operational and capital costs in the H-DR context considering process integration options. It is concluded that the use of $\mathrm{MeOH}$ is promising compared to the other considered carriers. For large storage volumes, $\mathrm{MeOH}$-based $\mathrm{H}_{2}$ storage may also be an attractive option to the underground storage of compressed $\mathrm{H}_{2}$. The other considered liquid $\mathrm{H}_{2}$ carriers suffer from large thermodynamic barriers for hydrogenation (FA) or dehydrogenation $\left(\mathrm{NH}_{3}, \mathrm{H} 18\right.$-DBT) and higher investment costs. However, for the use of $\mathrm{MeOH}$ in an $\mathrm{H}-\mathrm{DR}$ process to be practically feasible, questions regarding process flexibility and the optimal sourcing of $\mathrm{CO}_{2}$ and heat must be answered.

Keywords: fossil-free steel; hydrogen storage; liquid hydrogen carriers; hydrogen direct reduction; industrial decarbonization

\section{Introduction}

Steelmaking is responsible for approximately one third of industrial carbon dioxide $\left(\mathrm{CO}_{2}\right)$ emissions [1]. In order to meet the demands of the Paris Agreement and avoid the worst consequences of climate change, these emissions must be reduced drastically within the coming decades [2,3]. This is not achievable with the currently dominating steelmaking route based on blast furnace (BF) technology [4].

The most energy and emission-intensive step of BF steelmaking is the removal of oxygen from iron ore, i.e., the reduction in iron oxides (mainly hematite, $\mathrm{Fe}_{2} \mathrm{O}_{3}$ ) to produce iron $(\mathrm{Fe})$. In the $\mathrm{BF}$, this reduction is primarily achieved via reaction with coke, which is produced from fossil coal. As the iron oxides are reduced, the coke is oxidized to form $\mathrm{CO}_{2}$ (either directly, or via the initial formation of carbon monoxide (CO) that is later combusted to provide heat). Consequently, as long as coke is the main reducing agent, $\mathrm{CO}_{2}$ will be an unavoidable byproduct of BF steelmaking. At best, modern BF-based steelmaking results in around 1.6-1.9 tons of $\mathrm{CO}_{2}$ per ton of steel produced $[5,6]$.

In addition to iron ore, steel can also be produced from recycled steel scrap, most often using an electric arc furnace (EAF). This is referred to as secondary steelmaking. In the European Union (EU), 39\% of all steel is produced via this secondary route [6]. As the recycled steel has already been reduced, secondary steelmaking requires significantly less 
energy and produces far less $\mathrm{CO}_{2}$ than production starting from iron ore in a BF. Therefore, increasing steel recycling is an effective route towards decreasing the $\mathrm{CO}_{2}$ footprint of steel [7]. However, it is predicted that there will still be a substantial demand for iron orebased steelmaking in 2050, even with increased steel recycling [8]. To meet this demand, it is necessary to develop new iron ore reduction processes that can achieve near-zero $\mathrm{CO}_{2}$ emissions.

One promising way towards the decarbonization of iron ore-based steelmaking is hydrogen $\left(\mathrm{H}_{2}\right)$ direct reduction $(\mathrm{H}-\mathrm{DR})$. In $\mathrm{H}-\mathrm{DR}$, iron ore is reduced by $\mathrm{H}_{2}$, yielding only water $\left(\mathrm{H}_{2} \mathrm{O}\right)$ as a byproduct. This process is called direct reduction as the produced iron, referred to as direct reduced iron (DRI) or sponge iron, remains in the solid phase (direct reduction without melting). The main reducing reaction in H-DR can be summarized as

$$
\mathrm{Fe}_{2} \mathrm{O}_{3}+3 \mathrm{H}_{2} \rightarrow 2 \mathrm{Fe}+3 \mathrm{H}_{2} \mathrm{O}\left(\Delta \mathrm{H}_{\mathrm{R}}^{\mathrm{O}}=99 \mathrm{~kJ} / \mathrm{mol}\right)
$$

Note that reaction (1) is endothermic, which means that the incoming $\mathrm{H}_{2}$ must be pre-heated to a high temperature $\left(>800^{\circ} \mathrm{C}\right)$ to provide sufficient heat for the reaction.

$\mathrm{H}-\mathrm{DR}$ requires substantial supply of $\mathrm{H}_{2}$. By the stoichiometry of reaction (1), approximately $54 \mathrm{~kg}$ of $\mathrm{H}_{2}$ is needed to produce $1 \mathrm{t}$ of pure Fe. In practice, some unreduced material remains in the product DRI due to thermodynamic limitations [9]. Typically, around $94 \%$ of incoming $\mathrm{Fe}_{2} \mathrm{O}_{3}$ is fully reduced in commercial DR processes based on natural gas; this yields a $\mathrm{H}_{2}$ consumption of around $51 \mathrm{~kg} / \mathrm{t}$ DRI [10-12]. Consequently, for the production of $2 \mathrm{Mt}$ of steel per year, similar to the current production at the SSAB Luleå plant (a relatively small plant by European standards [13]), approximately $300 \mathrm{t}$ of $\mathrm{H}_{2}$ would be consumed per day [14].

Reduction of iron ore with pure $\mathrm{H}_{2}$ is not an entirely novel concept. The world's first, and, to date, only, H-DR plant went into operation in 1998 in Point Lisas, Trinidad; however, that plant closed down in 2016 due to poor economic performance [5,15]. In recent years, interest in $\mathrm{H}_{2}$ steelmaking is growing, with several industrial projects pursuing $\mathrm{H}$ DR, including HYBRIT (SSAB, LKAB and Vattenfall, Sweden), H2FUTURE (voestalpine, Austria), and SALCOS (Salzgitter, Germany) [16,17]. In addition, both ArcelorMittal and thyssenkrupp are planning to implement H-DR at their Hamburg and Duisburg sites, respectively [18-20].

It should be noted that while no $\mathrm{CO}_{2}$ is released during the reduction of iron ore with $\mathrm{H}_{2}$ (per reaction (1)), the production of the fed $\mathrm{H}_{2}$ may be associated with significant $\mathrm{CO}_{2}$ emissions, in particular when starting from natural gas (as was the case for the Trinidad $\mathrm{H}$-DR plant), oil or coal. Therefore, $\mathrm{H}$-DR based on $\mathrm{H}_{2}$ produced from fossil fuels is not attractive if the goal is to eliminate or heavily reduce the $\mathrm{CO}_{2}$ emissions of steelmaking, at least as long as the byproduct $\mathrm{CO}_{2}$ is not captured and stored. Currently, approximately $96 \%$ of global $\mathrm{H}_{2}$ production is from fossil fuels [21].

The presently most feasible way to produce $\mathrm{H}_{2}$ without emitting significant $\mathrm{CO}_{2}$ is the electrolysis of $\mathrm{H}_{2} \mathrm{O}$. In electrolysis, $\mathrm{H}_{2} \mathrm{O}$ is split into $\mathrm{H}_{2}$ and oxygen $\left(\mathrm{O}_{2}\right)$ using electricity. If this electricity is produced from fossil-free sources, $\mathrm{H}_{2}$ can be produced with near-zero $\mathrm{CO}_{2}$ emissions. The principal downside of electrolysis is the large electricity demand: state-of-the-art electrolyzers require around $50 \mathrm{kWh}$ of electricity to produce $1 \mathrm{~kg}$ of $\mathrm{H}_{2}$. As a result, full-scale implementation of H-DR with electrolysis to replace existing BF capacity involves substantial amounts of electricity-complete conversion of the current EU steel capacity could require up to $18 \%$ of the current EU electricity consumption $[8,22]$.

The high electricity demand of electrolysis means that the $\mathrm{H}_{2}$ production cost depends heavily on the price of electricity. As the electricity price varies over time, in particular when a large share is generated from intermittent sources such as solar and wind, it is sensible to consider the use of $\mathrm{H}_{2}$ storage. Such a storage allows for $\mathrm{H}_{2}$ to be produced predominantly during times with lower electricity prices, yielding a lower average electricity cost, while still maintaining constant DRI production. 


\section{Hydrogen Storage in Hydrogen Direct Reduction Context}

For investment into a $\mathrm{H}_{2}$ storage as part of an $\mathrm{H}-\mathrm{DR}$ process to be sensible, the prospective reduction in $\mathrm{H}_{2}$ production electricity cost must at least make up for the capital expenditure (CAPEX) of the storage and the associated electrolyzer overcapacity as well as the average operational expenditure (OPEX) of the storage and release processes, e.g., the costs of any additional electricity and heat. Therefore, $\mathrm{H}_{2}$ storage in the H-DR context should be:

- $\quad$ Low in investment cost (low CAPEX);

- Efficient, i.e., require little additional electricity and heat (low OPEX);

- Dynamic, i.e., it should be possible to change the operating mode of the storage (e.g., from filling to emptying) rapidly enough to respond to electricity price changes.

In terms of dynamics, it should be possible to empty the storage at a sufficient rate to be able to significantly turn down the electrolyzers when desired, i.e., during periods of high electricity prices. Ideally, the entire $\mathrm{H}$-DR process would run on stored $\mathrm{H}_{2}$ during electricity price peaks, allowing electrolyzers to operate at minimum load or be turned off (hot or cold standby) [23]. The minimum desired response time for storage operating mode changes is presently unclear. That said, significant day-to-day load changes would likely be required, at least, considering the dynamics of intermittent renewable energy sources.

The storage of $\mathrm{H}_{2}$ is challenging due to its low density and high reactivity. Moreover, as $\mathrm{H}_{2}$ has historically most often been produced from natural gas, oil, or coal, all more easily storable substances than $\mathrm{H}_{2}$, there has been little incentive to develop $\mathrm{H}_{2}$ storage technologies. Consequently, only a few large-scale storages of pure $\mathrm{H}_{2}$ exist today. All of these are large underground man-made pockets in salt formations filled with compressed gaseous $\mathrm{H}_{2}$ (up to around 230 bar) [24]. These facilities, referred to as salt cavern storages, are generally considered to be the most favorable large-scale $\mathrm{H}_{2}$ storage option in terms of overall economics, resulting from their low-cost construction via leaching and the gas impermeability of the salt; examples of operating $\mathrm{H}_{2}$ salt cavern storages are found in the UK and the USA [25-27]. Unfortunately, salt formations suitable for these storages are not ubiquitous [28]. For instance, no suitable salt formations exist in Sweden and many regions of the USA [29]. Therefore, other types of $\mathrm{H}_{2}$ storage must be sought in certain regions. For instance, in the HYBRIT project, the pursued $\mathrm{H}_{2}$ storage option is the lined rock cavern (LRC) technology [5]. An LRC is a type of underground storage made up of a steel- and concrete-lined cylindrical hard rock cavern $[24,29,30]$. The presence of the hard crystalline rock of the Baltic shield covering large parts of Sweden makes implementation of an LRC storage feasible in the HYBRIT project, although investment costs are significantly higher than for salt cavern storage [28]. In other words, certain geological conditions are also necessary to construct an LRC storage. There are also mechanical limits to $\mathrm{H}_{2}$ withdrawal rates from underground storages that may limit their appeal in the H-DR context [24]. For salt cavern and LRC storages, allowable rates lie in the range of $6-15 \%$ of the maximum storage capacity per day $[24,26,31,32]$.

The dependence on local geology and the limitations in the withdrawal rate of underground $\mathrm{H}_{2}$ storage opens up the possibility of utilizing alternative $\mathrm{H}_{2}$ storage technologies in $\mathrm{H}-\mathrm{DR}$ processes. One such alternative technology is based on so-called liquid $\mathrm{H}_{2}$ carriers, which will be explored in this work.

\section{Liquid Hydrogen Carriers}

\subsection{Overview}

By chemically reacting $\mathrm{H}_{2}$ with a secondary chemical substance, it is possible to form so-called liquid $\mathrm{H}_{2}$ carriers. Due to the high reactivity of $\mathrm{H}_{2}$, these hydrogenation reactions tend to be exothermic, i.e., heat-producing. Liquid carriers allow for $\mathrm{H}_{2}$ to be stored at a high volumetric density in liquid form, enabling compact storage and low-cost transportation. When $\mathrm{H}_{2}$ is subsequently needed, the carriers may be dehydrogenated in thermochemical endothermic processes to produce $\mathrm{H}_{2}$ and the original secondary substance. The low-cost storage and transportation of liquid $\mathrm{H}_{2}$ carriers introduces a number 
of opportunities for flexibility in the H-DR process that would not be possible, or at least as attractive, for a gaseous storage. A few examples are:

- Import and export of the liquid $\mathrm{H}_{2}$ carrier to or from the H-DR site is readily achieved;

- Placement of the $\mathrm{H}_{2}$ production and storage units becomes less geographically constrained;

- Very large $\mathrm{H}_{2}$ storages are possible, covering, e.g., seasonal variations in electricity price.

The typical downsides of using liquid $\mathrm{H}_{2}$ carriers are the high heat demand of the dehydrogenation process and the high investment costs of the necessary hydrogenation and dehydrogenation plants. In addition, the hydrogenation process typically involves the compression of gases (at least $\mathrm{H}_{2}$ ), requiring an often-significant input of electricity. Dynamic operation of the hydrogenation and dehydrogenation facilities in response to electricity price changes is also often unknown, limited or, at least, unconfirmed.

Although all liquid $\mathrm{H}_{2}$ carriers share the characteristics above, there are a number of additional factors to weigh when choosing the optimal carrier in the H-DR context. Numerous liquid $\mathrm{H}_{2}$ carriers have been suggested in the scientific literature, but relatively few have been studied outside of gram-scale laboratory experiments and theoretical models [33]. In the coming sections, these most widely discussed liquid $\mathrm{H}_{2}$ carriers will be described. They can be categorized into three groups:

(1) Those based on a reaction between $\mathrm{H}_{2}$ and $\mathrm{CO}_{2}$ (e.g., methanol $\left(\mathrm{CH}_{3} \mathrm{OH}, \mathrm{MeOH}\right)$ and formic acid $\left.\left(\mathrm{CH}_{2} \mathrm{O}_{2}, \mathrm{FA}\right)\right)$;

(2) Those based on a reaction between $\mathrm{H}_{2}$ and nitrogen $\left(\mathrm{N}_{2}\right)$ (e.g., ammonia $\left(\mathrm{NH}_{3}\right)$ );

(3) Those based on a reaction between $\mathrm{H}_{2}$ and unsaturated liquid hydrocarbons (liquid organic hydrogen carriers (LOHCs)).

Based on current technology, these carriers could be implemented for large-scale $\mathrm{H}_{2}$ storage within the context of a fossil-free H-DR process, although no such storage has yet been demonstrated at an industrial scale. The main reasons for this are the generally significant similarities between such storage systems and existing large-scale industrial chemical processes.

\subsection{Integration of Liquid Hydrogen Carriers in Hydrogen Direct Reduction Processes}

The prospective integration of the considered liquid $\mathrm{H}_{2}$ carriers in an $\mathrm{H}$-DR process is seen in Figure 1.

As can be seen, the choice of liquid $\mathrm{H}_{2}$ carrier affects the overall layout of the H-DR process somewhat, although the general principle is the same with all carriers: (mainly) electricity must be supplied for the hydrogenation process and (mainly) heat for the dehydrogenation process. The supply of dehydrogenation heat can be achieved in several ways, as shall be discussed below. In addition, the handling of the secondary material with which $\mathrm{H}_{2}$ reacts differs depending on the chosen carrier, with $\mathrm{CO}_{2}$-based carriers as particularly special cases.

\subsubsection{Management of Secondary Material}

For the non- $\mathrm{CO}_{2}$-based carriers, management of the secondary material is relatively simple. In the case of $\mathrm{NH}_{3}, \mathrm{~N}_{2}$ is sourced from the atmosphere via air separation (into $\mathrm{O}_{2}$ and $\mathrm{N}_{2}$ ), a well-established process [34]. After dehydrogenation, $\mathrm{N}_{2}$ is returned to the atmosphere. For LOHCs, the dehydrogenated ("unloaded") LOHC carrier must be stored. As this unloaded carrier is typically also a liquid, its separation from released $\mathrm{H}_{2}$ and storage is relatively straightforward.

For $\mathrm{CO}_{2}$-based storage, the situation is more complex. Sourcing $\mathrm{CO}_{2}$ from the air is far less viable compared to $\mathrm{N}_{2}$ due to its much lower concentration (around $0.04 \%$ vs. $78 \%$ by volume), although this is, in principle, possible and is a technology under development $[35,36]$. Therefore, all $\mathrm{CO}_{2}$ released upon dehydrogenation of the $\mathrm{CO}_{2}$-based carriers is preferably captured, instead of released to the atmosphere, and recycled to produce new $\mathrm{H}_{2}$ carrier. However, in practice, such operation is unlikely due to losses 
during the storage cycle and the cost of $\mathrm{CO}_{2}$ storage. Therefore, additional $\mathrm{CO}_{2}$ must be supplied to the storage process, although the recycling and storage of some amount of $\mathrm{CO}_{2}$ may be attractive to reduce the demand for external carbon in certain cases.

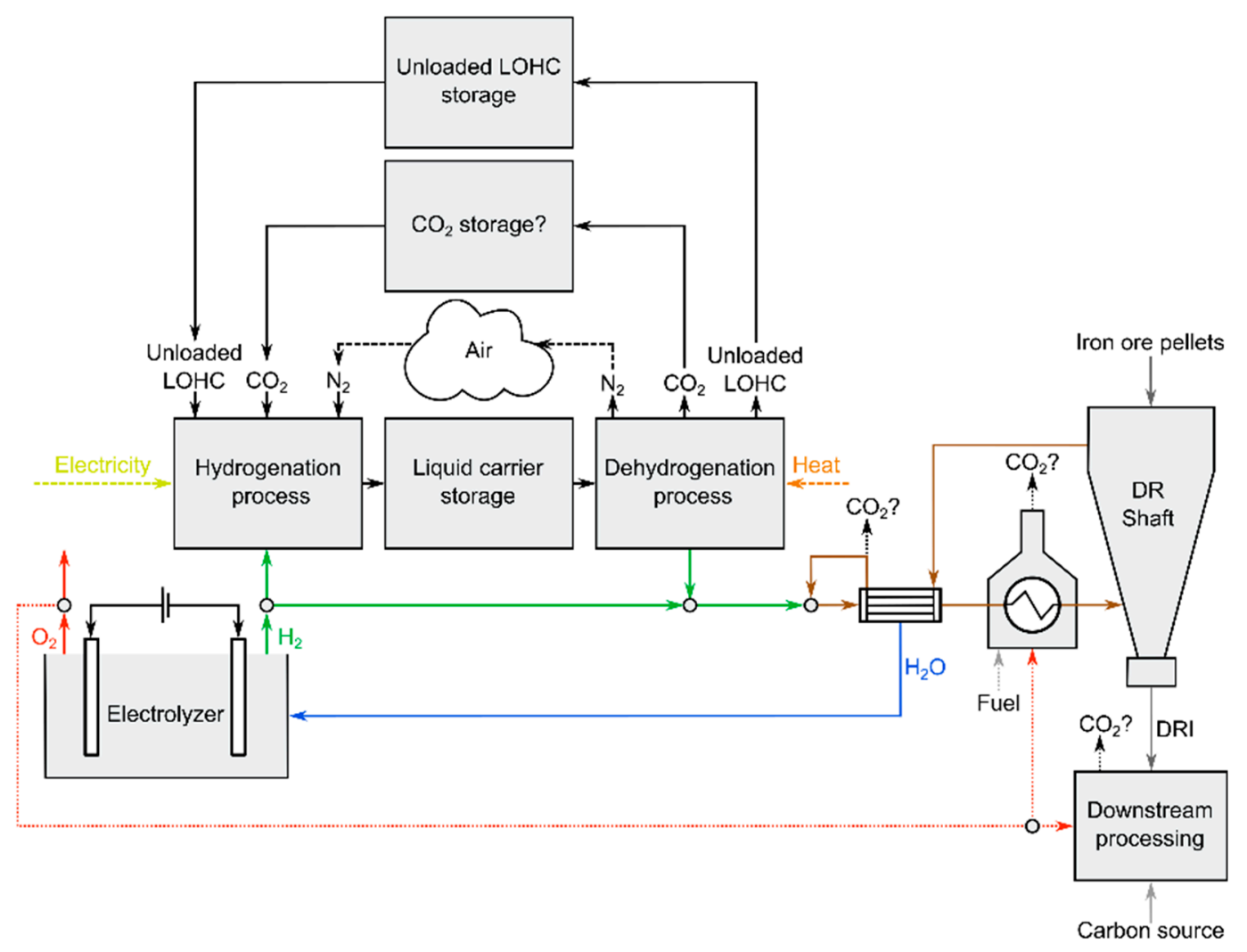

Figure 1. Schematic representation of the integration of various liquid hydrogen carriers in an $\mathrm{H}-\mathrm{DR}$ process. Possible $\mathrm{CO}_{2}$ sources are indicated (separation from DR process reducing gas, oxy-fuel combustion reducing gas pre-heating, separation from downstream processing steps).

Additional $\mathrm{CO}_{2}$ for $\mathrm{H}_{2}$ storage can be sourced in several ways. Within the H-DR process, one can imagine at least three sources, as seen in Figure 1:

(1) the separation of $\mathrm{CO}_{2}$ from the reducing gas in the case that in-shaft carburization would be applied;

(2) the reducing gas pre-heating process;

(3) the processing steps downstream of the DR shaft (e.g., the electric arc furnace (EAF)).

Out of these options, the pre-heating route appears the most attractive and generally applicable. Pre-heating via the use of biomass oxy-fuel combustion to co-produce $\mathrm{CO}_{2}$ for $\mathrm{MeOH}$ production in an H-DR process was evaluated in a recent study [37]. In the case that oxy-fuel combustion of biomass is used to pre-heat the reducing gas to $700{ }^{\circ} \mathrm{C}$, the $\mathrm{CO}_{2}$ generated is sufficient to allow for a $41 \%$ electrolyzer overcapacity, with sufficient amounts of $\mathrm{O}_{2}$ generated by electrolyzers to fully feed the combustion process. Compared to other $\mathrm{CO}_{2}$-sourcing options, oxy-fuel combustion of biomass appears to be attractive in that it serves multiple functions within the $\mathrm{H}$-DR process. It would also constitute a relatively constant source of biogenic $\mathrm{CO}_{2}$. In contrast, capturing $\mathrm{CO}_{2}$ from downstream processes would likely entail additional costs with few co-benefits. In the case that in-shaft carburization is applied, the capture of $\mathrm{CO}_{2}$ from the top gas would be necessary to avoid its accumulation in the reducing gas loop. Therefore, utilizing this $\mathrm{CO}_{2}$ to store $\mathrm{H}_{2}$ could potentially also be an attractive option. However, the feasibility and general attractiveness of in-shaft carburization in a fossil-free H-DR process is currently unclear. While carbon is 
an unavoidable part of steelmaking, it may also be viable to introduce this downstream of the reduction process, e.g., in the EAF, rendering in-shaft carburization unnecessary [38,39].

Finally, the import of $\mathrm{CO}_{2}$ to the H-DR site may also be a feasible solution. The importance of the biogenic origin of such imported $\mathrm{CO}_{2}$ must be emphasized. If the $\mathrm{CO}_{2}$ is not biogenic in origin, the steelmaking process could not be considered fossil-free. The use of $\mathrm{CO}_{2}$ captured from pulp mills or from biogas (upgrading) plants are possible options [40]. Naturally, one could also consider the decentralized production of a liquid $\mathrm{H}_{2}$ carrier at the site with biogenic $\mathrm{CO}_{2}$ in such cases, considering the relative ease of transporting these carriers by ship, truck or rail. Investigation of such schemes, while potentially interesting, is considered outside of the scope of the present work.

\subsubsection{Management of Heat for Dehydrogenation}

As mentioned previously, a general feature of all liquid $\mathrm{H}_{2}$ carriers is the need to supply significant amounts of heat to the dehydrogenation process. The necessary heat amount and temperature level differs from carrier to carrier. For certain carriers, heat of different temperature levels is needed, e.g., for evaporation at a lower temperature followed by dehydrogenation in the gaseous phase at a higher temperature. Several heat supply options are conceivable. Ideally, surplus heat from the H-DR process would be used for dehydrogenation, as this is likely the lowest-cost option. Within the H-DR process there are several potential sources of such surplus heat. The most prominent examples include:

- Heat from electrolyzers;

- DRI product cooling in the case that cold DRI or hot-briquetted iron is produced [10];

- Excess heat from reduction gas pre-heating.

The amount of available heat from these sources can be approximated using basic thermodynamic data. Considering a $\mathrm{H}_{2}$ demand of $51 \mathrm{~kg} \mathrm{H}_{2} / \mathrm{t}$ DRI, an electrolyzer efficiency of $50 \mathrm{kWh}_{\mathrm{el}} / \mathrm{kg} \mathrm{H}_{2}$ yields approximately $560 \mathrm{kWh} / \mathrm{t}$ DRI of surplus heat from electrolyzers when at full load. Commercial alkaline and polymer electrolyte membrane (PEM) electrolyzers operate at $50-90{ }^{\circ} \mathrm{C}$ [41]. Upgrading this heat to higher temperatures using heat pumps could be an option [42,43]. Note that electrolyzers are predicted to operate at varying loads within a H-DR process, allowed for by the integration of the $\mathrm{H}_{2}$ storage. Therefore, heat from electrolyzers will be intermittent and mainly available during times of low electricity prices, rendering heat integration between electrolyzers and the dehydrogenation process challenging.

The sensible heat available from DRI cooling can be significant in an industrial-scale HDR process: assuming that the DRI exits the reduction shaft at $850^{\circ} \mathrm{C}$ and has a specific heat capacity of $0.56 \mathrm{MJ} /(\mathrm{t}, \mathrm{K})$, around $0.1 \mathrm{MW} /(\mathrm{t} \mathrm{DRI} / \mathrm{h})$ down to $20{ }^{\circ} \mathrm{C}$ [12,37]. However, it is not certain that this heat will be available as the direct transfer of hot DRI from the reduction shaft to the EAF reduces the electricity demand of the EAF [10]. A possibility that could enable the use of the DRI cooling heat is that EAF operation, which is electricity-intensive, is avoided during times of high electricity prices (when the dehydrogenation process is expected to be operated). However, the viability of such operation is presently unclear.

As the reduction of iron ore with $\mathrm{H}_{2}$ is an endothermic reaction (reaction (1)), the incoming $\mathrm{H}_{2}$ must be pre-heated to a high temperature before entering the reduction shaft. The heat required for this pre-heating is substantial in an industrial-scale H-DR process: approximately $10 \mathrm{kWh} / \mathrm{kg} \mathrm{H}_{2}$ of heat must be supplied if the reducing gas enters the reduction shaft at $900{ }^{\circ} \mathrm{C}$ [37]. The excess heat from reduction gas pre-heating depends on what heating technology is used. For instance, for electric heating, the amount of excess heat would be negligible. However, even if oxy-fuel pre-heating is applied, as described previously, the amount of excess heat is likely too small to be useful for integration with a dehydrogenation plant [37].

In summary, heat integration between the dehydrogenation and H-DR processes is complicated and context-dependent. A major challenge is the intermittency of the dehydrogenation process. 
If heat integration with the H-DR process is not feasible or sufficient, other sources of heat for the dehydrogenation process are needed. Three alternatives are obvious: (1) combustion of part of the released $\mathrm{H}_{2}$ (or the liquid $\mathrm{H}_{2}$ carrier), (2) electric heating, and (3) external fuel. All these alternatives are associated with certain challenges or disadvantages.

Combustion of part of released $\mathrm{H}_{2}$ is a straightforward approach, and is typically applied in fossil-fuel-based $\mathrm{H}_{2}$ production. The combusted $\mathrm{H}_{2}$ can often be sourced from the downstream separation step (e.g., pressure swing adsorption (PSA)), which generally results in one near-pure $\mathrm{H}_{2}$ stream and one dilute $\mathrm{H}_{2}$ stream suitable for combustion [44-46]. However, the conversion losses associated with electrolysis renders $\mathrm{H}_{2}$ combustion an expensive source of heat. Furthermore, if only part of the stored $\mathrm{H}_{2}$ can be delivered to the H-DR process upon dehydrogenation, the storage and the hydrogenation process must be oversized accordingly, adding investment and operational costs. The direct use of electric heating is potentially more efficient, but is, as of yet, not commercially available for the dehydrogenation processes of interest here (the main reason for this is that combustion of natural gas has historically been a lower-cost source of heat than direct use of electricity, rendering the development of such reactors uninteresting), although developments are underway $[44,47]$. A downside here is that the dehydrogenation process should ideally only run during times of high electricity prices, which could also render electrified dehydrogenation expensive, despite the higher efficiency compared to $\mathrm{H}_{2}$ combustion. The third option, combustion of an external fuel, is potentially limited by the availability and cost of fossil-free fuels (biomass, biofuels) [48]. Only in certain regions, e.g., Sweden, is the direct use of forest residues potentially a low-cost option [49].

\subsection{Carbon Dioxide-Based Carriers}

Several reactions are possible between $\mathrm{H}_{2}$ and $\mathrm{CO}_{2}$. For $\mathrm{H}_{2}$ storage purposes, the most useful products are those that are simultaneously liquids at room temperature and can be dehydrogenated at low cost. This limits the number of contenders significantly. Carbon monoxide $(\mathrm{CO})$ and methane $\left(\mathrm{CH}_{4}\right)$ are both gaseous at room temperature and require large inputs of high-temperature heat to release $\mathrm{H}_{2}$. Formaldehyde $\left(\mathrm{CH}_{2} \mathrm{O}\right)$ is also a gas at room temperature (normal boiling point $-19^{\circ} \mathrm{C}$ ), although formaldehyde-water solutions are stable. However, the direct synthesis of $\mathrm{CH}_{2} \mathrm{O}$ from $\mathrm{CO}_{2}$ and $\mathrm{H}_{2}$ is challenging, mainly due to thermodynamics and selectivity issues, limiting its appeal as a $\mathrm{H}_{2}$ carrier [50].

The two most investigated $\mathrm{CO}_{2}$-based liquid $\mathrm{H}_{2}$ carriers are methanol $\left(\mathrm{CH}_{3} \mathrm{OH}\right.$, $\mathrm{MeOH})$ and formic acid $\left(\mathrm{CH}_{2} \mathrm{O}_{2}, \mathrm{FA}\right)$. Out of these, $\mathrm{MeOH}$ is currently the most mature option, as both $\mathrm{MeOH}$ production from $\mathrm{CO}_{2}$ and $\mathrm{MeOH}$ reforming may be considered established industrial processes. In contrast, converting $\mathrm{H}_{2}$ and $\mathrm{CO}_{2}$ to $\mathrm{FA}$ is rather complex. Several processes have been suggested in recent years, but industrial application has not yet occurred [51,52]. Nevertheless, FA remains a $\mathrm{H}_{2}$ storage option with significant potential. In particular, it may prove feasible to release $\mathrm{H}_{2}$ from $\mathrm{FA}$ at near-room temperature, given that viable catalysts are developed [51].

\subsubsection{Methanol}

Methanol $(\mathrm{MeOH})$ is the simplest alcohol, containing $12.6 \% \mathrm{H}_{2}$ by weight. Its current production is nearly entirely based on natural gas or coal feedstocks. However, the direct production of $\mathrm{MeOH}$ from $\mathrm{CO}_{2}$ and $\mathrm{H}_{2}$ using a near-identical process is possible and has been commercialized, with the most notable example being the "George Olah Renewable Methanol Plant" operated by CRI (Carbon Recycling International) on Iceland, although that plant is relatively small at $4000 \mathrm{t} \mathrm{MeOH/y} \mathrm{[53,54].} \mathrm{The} \mathrm{main} \mathrm{economic} \mathrm{barrier} \mathrm{of}$ $\mathrm{CO}_{2}$-based $\mathrm{MeOH}$ production is the cost of producing $\mathrm{H}_{2}$ via electrolysis [55].

The production of $\mathrm{MeOH}$ from $\mathrm{CO}_{2}$ and $\mathrm{H}_{2}$ is exothermic and endergonic at ambient conditions [50]. The only byproduct of the reaction is $\mathrm{H}_{2} \mathrm{O}$ that may be separated via distillation.

$$
\mathrm{CO}_{2}+3 \mathrm{H}_{2} \rightarrow \mathrm{CH}_{3} \mathrm{OH}+\mathrm{H}_{2} \mathrm{O}\left(\Delta \mathrm{H}^{\mathrm{o}}{ }_{\mathrm{R}}=-49 \mathrm{~kJ} / \mathrm{mol}\right)
$$


The formation of $\mathrm{MeOH}$ is thermodynamically promoted by high pressures and low temperatures. However, due to kinetic reasons, elevated reactor temperatures of around $250{ }^{\circ} \mathrm{C}$ are typical [56]. As a result, complete conversion of the reactants is not achieved in a single pass through the reactor, necessitating recycling, as seen in Figure 2 . To avoid the accumulation of inerts in the reactor loop, a purge stream is required. A $1 \mathrm{~mol} \%$ purge has been reported, but the amount depends on the purity of the inlet $\mathrm{CO}_{2}$ (electrolysis produces very pure $\mathrm{H}_{2},>99.5 \%$ for all conventional technologies) $[57,58]$.

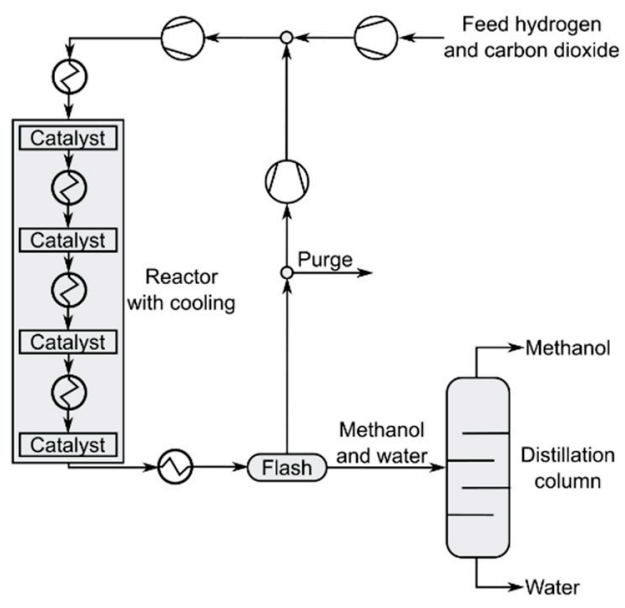

Figure 2. Generic $\mathrm{CO}_{2}$-based $\mathrm{MeOH}$ production process [37].

The most commonly applied catalyst for $\mathrm{CO}_{2}$-based $\mathrm{MeOH}$ production is based on copper $(\mathrm{Cu}): \mathrm{Cu} / \mathrm{ZnO} / \mathrm{Al}_{2} \mathrm{O}_{3}$ [59-61]. This catalyst is relatively cheap and has been proven to be able to operate under fluctuating conditions [60-62]. Minimum loads down to $10 \%$ of the design capacity should be possible in $\mathrm{CO}_{2}$-based $\mathrm{MeOH}$ production [63].

The production of $\mathrm{MeOH}$ from $\mathrm{CO}_{2}$ is, as mentioned, an exothermic process. In practice, the heat generated via this reaction is more than sufficient to cover the heat demand of the rest of the storage process, i.e., the overall hot utility demand is negative [55,57]. This includes the separation of formed $\mathrm{MeOH}$ and $\mathrm{H}_{2} \mathrm{O}$ via distillation. In an H-DR process, where $\mathrm{MeOH}$ would principally be produced to store $\mathrm{H}_{2}$, this distillation step is unnecessary, as $\mathrm{MeOH}$ would be mixed with $\mathrm{H}_{2} \mathrm{O}$ during the dehydrogenation step (the reverse reaction of (1)) anyway [64].

The electricity demand of a $\mathrm{CO}_{2}$-based $\mathrm{MeOH}$ plant is rather low (excluding electrolysis). Compression of fed and recycled gases constitutes the main electricity consumption. In addition, a significant amount of electricity could theoretically also be generated via integration of steam turbines and organic Rankine cycles in the process $[55,57,65]$. Consequently, the net total electricity demand of the process is estimated at around -0.06 to $0.175 \mathrm{kWh} / \mathrm{kg} \mathrm{MeOH}\left(-0.3\right.$ to $0.9 \mathrm{kWh} / \mathrm{kg}$ stored $\left.\mathrm{H}_{2}\right)$ in the literature, indicating that the process can be self-sufficient or even export electricity $[40,55,57,65]$. Note that these values include distillation.

The dehydrogenation of $\mathrm{MeOH}$ may proceed via the reverse of reaction (2), which is called $\mathrm{MeOH}$ steam reforming (MSR). The basic layout of a MSR process is seen in Figure 3. The same kind of catalyst as in $\mathrm{CO}_{2}$-based $\mathrm{MeOH}$ production may be used, i.e., $\mathrm{Cu} / \mathrm{ZnO} / \mathrm{Al}_{2} \mathrm{O}_{3}$; consequently, using a single reactor for both hydrogenation and dehydrogenation processes may be possible, although this concept is yet unproven [66]. Using these catalysts, a high selectivity towards $\mathrm{CO}_{2}$, rather than $\mathrm{CO}$, can be achieved in MSR [67-70].

As the production of $\mathrm{MeOH}$ from $\mathrm{CO}_{2}$ and $\mathrm{H}_{2}$ is exothermic, MSR is endothermic. In addition, since MSR typically takes place in the gas phase at elevated temperatures (200-300 ${ }^{\circ} \mathrm{C}$ ), significant amounts of heat for the evaporation of $\mathrm{MeOH}$ and $\mathrm{H}_{2} \mathrm{O}$ must also be supplied. However, evaporation of $\mathrm{MeOH}$ and $\mathrm{H}_{2} \mathrm{O}$ can be achieved at a relatively low temperature (an equimolar mixture boils at $73^{\circ} \mathrm{C}$ ), which means that, e.g., electrolyzer 
waste heat could be utilized. If MSR is to completely supply a $2 \mathrm{Mt}$ DRI/y H-DR process with $\mathrm{H}_{2}$, around $50 \mathrm{MW}$ of evaporation heat $\left(<100{ }^{\circ} \mathrm{C}\right)$ and $30 \mathrm{MW}$ of reaction heat (200-300 ${ }^{\circ} \mathrm{C}$ ) must be supplied [37]. The separation of released $\mathrm{H}_{2}$ and $\mathrm{CO}_{2}$ is commonly achieved via PSA in existing MSR plants [71]. The energy demand of this separation process is low. PSA requires elevated inlet pressures, but the compression of gases can be avoided in MSR in favor of pumping of liquid $\mathrm{MeOH}$ and $\mathrm{H}_{2} \mathrm{O}$ with typical pressures of 10-25 bar [72,73]. Typically, as seen in Figure 3, heat is supplied via combustion of the PSA off-gas in MSR. This off-gas contains a small concentration of $\mathrm{H}_{2}$. If the off-gas is combusted to provide the entire heat demand of MSR, around 8-10\% of the stored $\mathrm{H}_{2}$ would be consumed $[33,68]$. Supplying this heat via electricity, e.g., via inductive heating, which has recently been patented, may also be an attractive approach, but has not yet been demonstrated at scale [47]. To the best knowledge of the author, no large-scale $\left(>100 \mathrm{t} \mathrm{H}_{2} / \mathrm{d}\right)$ MSR plant exists today. However, scale-up should be straightforward considering the low process complexity and that only standard equipment is needed [74].

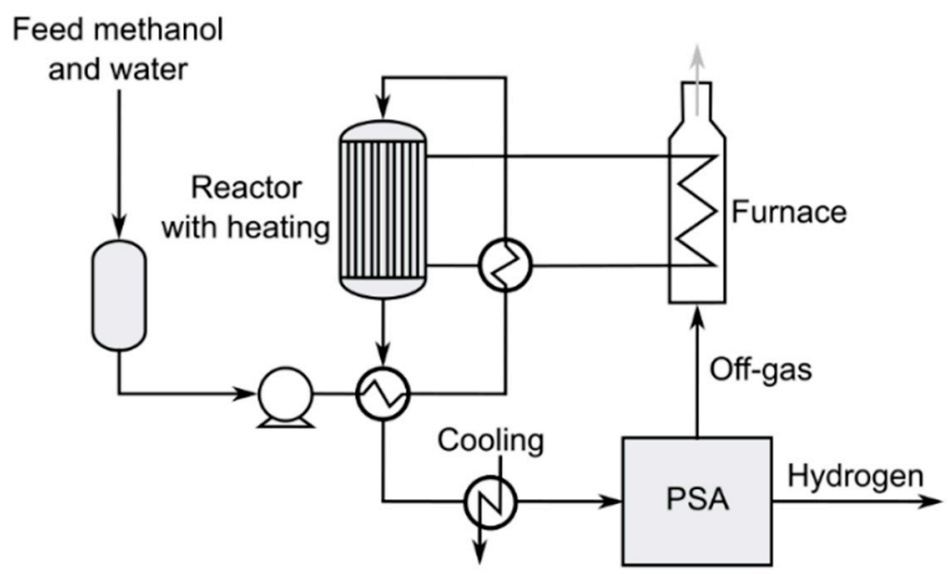

Figure 3. Conventional layout of a methanol steam reforming process [37].

\subsubsection{Formic Acid}

Formic acid $\left(\mathrm{CH}_{2} \mathrm{O}_{2}, \mathrm{FA}\right)$ is the simplest carboxylic acid. It is a liquid at room temperature (normal melting point is $8^{\circ} \mathrm{C}$ ). Compared to $\mathrm{MeOH}$, FA stores less $\mathrm{H}_{2}$ by weight $(4.4 \%)$, but the thermodynamic barrier for the release of $\mathrm{H}_{2}$ (and $\left.\mathrm{CO}_{2}\right)$ is significantly lower $[50,75]$.

In practice, $\mathrm{FA}$ is facing several challenges as a liquid $\mathrm{H}_{2}$ carrier, the most severe residing with the FA production step. FA can be formed via direct reaction between $\mathrm{H}_{2}$ and $\mathrm{CO}_{2}$

$$
\mathrm{CO}_{2}+\mathrm{H}_{2} \rightarrow \mathrm{CH}_{2} \mathrm{O}_{2}\left(\Delta \mathrm{H}^{\mathrm{o}}{ }_{\mathrm{R}}=-31 \mathrm{~kJ} / \mathrm{mol}\right)
$$

However, this reaction is strongly endergonic, and insignificant amounts of FA are formed, even at very high pressures [75-77]. This thermodynamic barrier can be overcome by performing the reaction in a basic solution, typically containing an amine, at high pressures (>100 bar) $[64,78,79]$. The amine scavenges any formed FA to produce formate salts. This salt formation pushes the equilibrium of reaction (2) towards FA. While this is advantageous in terms of the reaction equilibrium, other problems are created. Firstly, these formate salts are generally quite stable and, secondly, the acquired formate salt solutions tend to be very dilute [76]. Taken together, this means that the separation process becomes energy-intensive [79]. Estimates of the electricity and heat demand of $\mathrm{CO}_{2}$-based FA production are in the range of 3.6-6.7 and 16-63 (at 100-200 ${ }^{\circ} \mathrm{C}$ ) $\mathrm{kWh} / \mathrm{kg} \mathrm{H} \mathrm{H}_{2}$ stored, respectively $[78,79]$. This type of $\mathrm{CO}_{2}$-based FA production has not been demonstrated on a significant scale [80].

A way around the cumbersome separation is to not utilize FA as the $\mathrm{H}_{2}$ storage medium but instead the formate salt solutions. Formate salts $\left(\mathrm{MHCO}_{2}\right.$, where $\mathrm{M}=\mathrm{Na}, \mathrm{K}$, Cs or $\mathrm{NH}_{4}$ ) store $\mathrm{H}_{2}$ at a lower density than FA, theoretically around $20-28 \mathrm{~kg} \mathrm{H}_{2} / \mathrm{m}^{3}$ [81]. 
However, the reversible storage of $\mathrm{H}_{2}$ in these salts is far more thermodynamically advantageous (the hydrogenation reaction is mildly exergonic) [75]. In addition, there is, ideally, no release of $\mathrm{CO}_{2}$ along with $\mathrm{H}_{2}$ during dehydrogenation as a bicarbonate salt is formed instead, per reaction (4) (here the sodium-based system is shown as an example):

$$
\mathrm{NaHCO}_{2}+\mathrm{H}_{2} \mathrm{O} \rightarrow \mathrm{NaHCO}_{3}+\mathrm{H}_{2}\left(\Delta \mathrm{H}_{\mathrm{R}}^{\mathrm{o}}=-21 \mathrm{~kJ} / \mathrm{mol}\right)
$$

In practice, the achievable $\mathrm{H}_{2}$ storage density in formate salt solutions is limited by the solubility of the byproduct bicarbonate salts [76]. This limited solubility is detrimental to the efficiency of the $\mathrm{H}_{2}$ storage cycle, as large amounts of $\mathrm{H}_{2} \mathrm{O}$ must be heated to the reaction temperature during both hydrogenation and dehydrogenation (the exothermic enthalpy of hydrogenation does help somewhat). That said, the heat that must be supplied is at a relatively low temperature but above $100{ }^{\circ} \mathrm{C}$. The dehydrogenated bicarbonate salt solution must be stored, which would add some cost to the storage. While the use of formate salts for $\mathrm{H}_{2}$ storage is potentially attractive in the H-DR context, mainly due to the hypothetically low energy demand, no thorough techno-economic analysis of these types of systems is currently available in the literature.

As for the other liquid $\mathrm{H}_{2}$ carriers discussed herein, the dehydrogenation of FA or formate salt solutions requires an input of heat. However, unlike the other carriers considered in this work, the actual reaction enthalpy is not the most critical aspect [76]. Instead, preheating of FA or formate salt solutions to the reaction temperature dominates the overall heat demand. This means that the concentration of the FA or formate salt solutions is an important parameter. The total heat demand of FA or formate salt dehydrogenation can be estimated to be 2.8-9.1 (ranging from pure FA to aqueous FA at a concentration of $4 \mathrm{M}$ ) and $5.7 \mathrm{kWh} / \mathrm{kg} \mathrm{H}_{2}$, respectively [76]. Fortunately, the required temperature level of this heat is generally low $\left(<100^{\circ} \mathrm{C}\right)$, indicating that, e.g., waste heat from electrolyzers could be utilized. A disadvantage of FA compared to $\mathrm{MeOH}$ is the higher share of $\mathrm{CO}_{2}$ released with $\mathrm{H}_{2}$. This lower concentration of $\mathrm{H}_{2}$ in the dehydrogenation product gas means that more $\mathrm{CO}_{2}$ must be separated out per $\mathrm{kg}$ of $\mathrm{H}_{2}$ sent to the $\mathrm{H}-\mathrm{DR}$ process. However, the thermodynamics of FA dehydrogenation allow for high pressures (up to 700 bar), despite the co-release of gaseous $\mathrm{CO}_{2}$, to be attained directly without compression, which may ease the separation [82]. Most often, $\mathrm{Ru}$ - or Rh-based catalysts have been applied for FA dehydrogenation, although many different catalysts have been investigated; a major challenge is achieving both high activity and high selectivity towards $\mathrm{CO}_{2}[51,52,83-85]$.

\subsection{Ammonia}

$\mathrm{N}_{2}$-based $\mathrm{H}_{2}$ carriers, specifically $\mathrm{NH}_{3}$, may be attractive for $\mathrm{H}_{2}$ storage for a number of reasons. The $\mathrm{H}_{2}$ storage density of liquid $\mathrm{NH}_{3}$ is very high, at around $120 \mathrm{~kg} / \mathrm{m}^{3}$, over $150 \%$ the density of liquid $\mathrm{H}_{2}$ [86], although $\mathrm{NH}_{3}$ condenses at around $-33{ }^{\circ} \mathrm{C}$, which necessitates storage in well-insulated refrigerated containers (pressurized storage at ambient temperature is also possible, but is more costly at large scales). $\mathrm{NH}_{3}$ is formed via reaction between $\mathrm{H}_{2}$ and $\mathrm{N}_{2}$ in an exothermic reaction, typically as part of the well-known HaberBosch process

$$
3 \mathrm{H}_{2}+\mathrm{N}_{2} \rightarrow 2 \mathrm{NH}_{3}\left(\Delta \mathrm{H}_{\mathrm{R}}^{\mathrm{o}}=-92 \mathrm{~kJ} / \mathrm{mol}\right)
$$

Similar to $\mathrm{MeOH}$ production, the formation of $\mathrm{NH}_{3}$ is exergonic at ambient conditions and is favored by high pressures and low temperatures but is, in practice, operated at a high temperature [87]. The basic layout of the Haber-Bosch reactor loop is seen in Figure 4.

Typical reactor conditions are $150-250$ bar and $400-450{ }^{\circ} \mathrm{C}$, most often utilizing an iron-based catalyst [88]. Similarly to $\mathrm{MeOH}$, complete conversion is not achieved in a single pass through the reactor and recycling of unreacted $\mathrm{H}_{2}$ and $\mathrm{N}_{2}$ is necessary, with part of the recycle loop purged to prevent the accumulation of inerts in the reactor. However, the amount of inerts introduced into an electrolysis-based Haber-Bosch process should be sufficiently low to dissolve in the produced $\mathrm{NH}_{3}$, rendering a purge stream 
unnecessary [88]. $\mathrm{NH}_{3}$ is separated out from the recycle loop via condensation at -25 to $-33^{\circ} \mathrm{C}$, which necessitates refrigeration $[88,89]$. The need for refrigeration provides another reason for the high reactor pressure in the Haber-Bosch process: a lower pressure would lead to unpractically low $\mathrm{NH}_{3}$ condensation temperatures [90].

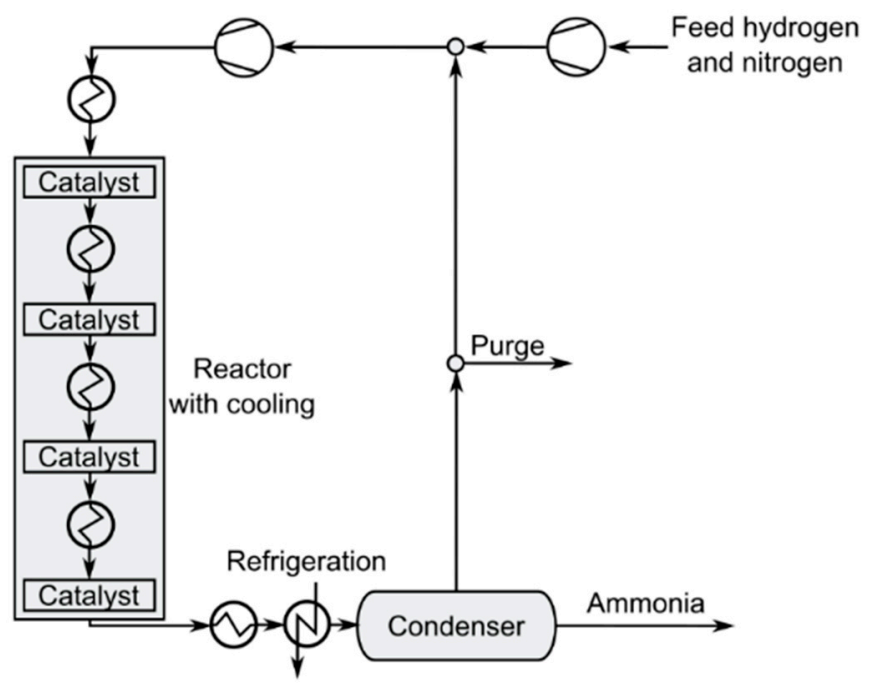

Figure 4. Generic layout of Haber-Bosch $\mathrm{NH}_{3}$ synthesis loop.

Unlike the other considered liquid $\mathrm{H}_{2}$ carriers, the atmosphere can be utilized as a vast reserve of relatively low-cost $\mathrm{N}_{2}$. Consequently, storage of $\mathrm{N}_{2}$ is not necessary and this saves costs. However, although $\mathrm{N}_{2}$ is plentiful in the atmosphere, air separation still requires a significant amount of energy. The most feasible process option at large scale is the use of cryogenic air separation units (ASUs). These require an electricity input of around $0.2-0.8 \mathrm{kWh} / \mathrm{kg} \mathrm{N}_{2}$, mainly for compression of the incoming air [91-94]. Translated to electricity per $\mathrm{H}_{2}$ stored in $\mathrm{NH}_{3}$, this is $2.3-3.7 \mathrm{kWh} / \mathrm{kg} \mathrm{H}$. Considering the high pressure of $\mathrm{NH}_{3}$ synthesis, it can be concluded that this is the most electricity-intensive hydrogenation process of the ones considered. Estimated total electricity demands of ASU operation and $\mathrm{NH}_{3}$ production are in the range of $0.6-1.1 \mathrm{kWh} / \mathrm{kg} \mathrm{NH}_{3}$ in the literature, equivalent to $3.4-6.2 \mathrm{kWh} / \mathrm{kg}$ stored $\mathrm{H}_{2}$.

The dehydrogenation or "cracking" of $\mathrm{NH}_{3}$, the reverse reaction of (5), requires high temperatures due to both thermodynamic and kinetic reasons [95]. No large-scale $\mathrm{NH}_{3}$ cracking plant exists today [96]. However, one can imagine a layout similar to current steam methane reformers (SMRs) that produce $\mathrm{H}_{2}$ from natural gas. A recent report from the project "Ammonia to Green Hydrogen" investigated a hypothetical such large-scale $\mathrm{NH}_{3}$ cracker capable of delivering $200 \mathrm{t} \mathrm{H}_{2} / \mathrm{d}$ [96]. The heat demand of the cracker was found to be $119 \mathrm{MW}$ (in terms of fuel lower heating value, equivalent to $14.3 \mathrm{kWh} / \mathrm{kg}$ $\mathrm{H}_{2}$ ). The combusted fuel is assumed to be a mixture of $\mathrm{NH}_{3}$ and $\mathrm{H}_{2}$. Around $15 \mathrm{MW}$ of electricity could also be co-produced from the generated steam ( $\left.40 \mathrm{bar}, 345^{\circ} \mathrm{C}\right)$. The separation of $\mathrm{H}_{2}$ from $\mathrm{N}_{2}$ and any remaining $\mathrm{NH}_{3}$ is achieved using a cryogenic process. This cryogenic process, which also produces liquid $\mathrm{N}_{2}$, requires an electricity input of 1.8 MW (approximately $0.2 \mathrm{kWh} / \mathrm{kg} \mathrm{H}_{2}$ ). It should be noted that the product of this model plant is fuel cell grade $\mathrm{H}_{2}$ at 250 bar. In a future H-DR process, compression and purity demands would be significantly lower, leading to savings in both operational and investment costs. Nevertheless, the need for large amounts of high-temperature heat for $\mathrm{NH}_{3}$ dehydrogenation remains a significant obstacle. Additionally, the $\mathrm{NH}_{3}$ dehydrogenation process would have to be operated dynamically in the context of an H-DR process. The viability of such operation is currently unknown. 


\subsection{Liquid Organic Hydrogen Carriers}

Unlike for the $\mathrm{CO}_{2}$ - and $\mathrm{N}_{2}$-based carriers previously described, the dehydrogenated forms of liquid organic $\mathrm{H}_{2}$ carriers (LOHCs) are liquid [97,98]. Consequently, $\mathrm{H}_{2}$ is the only gaseous product of the dehydrogenation process and a gas separation step can be avoided (compared to the previously considered carriers, where the separation of $\mathrm{CO}_{2}$ or $\mathrm{N}_{2}$ is necessary) [98].

As with the previously discussed liquid $\mathrm{H}_{2}$ carriers, the hydrogenation of LOHCs is exothermic, while dehydrogenation is endothermic. However, these energetic barriers tend to be larger for LOHCs. The most widely discussed LOHC is perhydro-dibenzyltoluene (H18-DBT, dehydrogenated form is dibenzyltoluene (DBT)). As H18-DBT/DBT is the $\mathrm{LOHC}$ that has received the most attention in the recent scientific literature, it will be the main LOHC investigated here. More thorough reviews of LOHC technology can be found elsewhere [99-103]. To supply the necessary heat for the dehydrogenation of H18-DBT, around $30 \%$ of released $\mathrm{H}_{2}$ must be combusted [91,104]. This is a clear disadvantage of H18-DBT and LOHCs in general. Certainly, if surplus heat from a nearby process can be used for the dehydrogenation step, the attractiveness of LOHCs increases [99]. A full supply of $\mathrm{H}_{2}$ via H18-DBT dehydrogenation to an industrial-scale $\mathrm{H}$-DR process producing $2 \mathrm{Mt} \mathrm{DRI} / \mathrm{y}$ would require approximately $100 \mathrm{MW}$ of heat $\left(>300^{\circ} \mathrm{C}\right)$. The H18-DBT/DBT $\mathrm{H}_{2}$ storage cycle is shown in Figure 5.

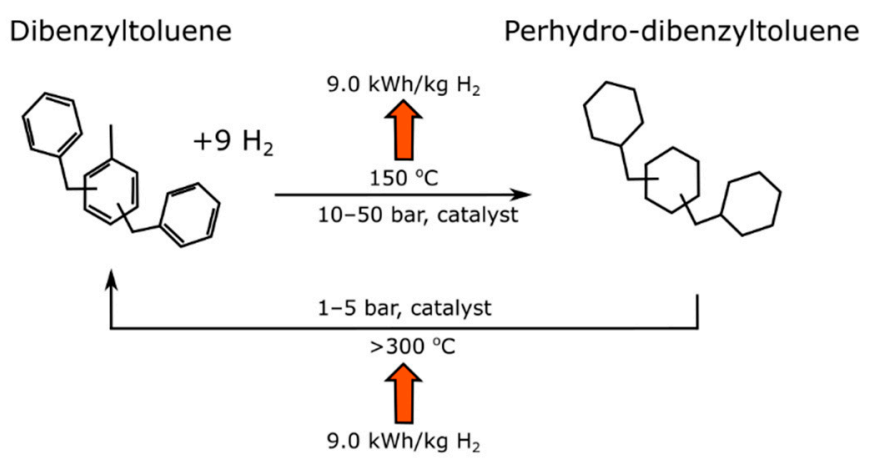

Figure 5. Hydrogen storage cycle for (perhydro-)dibenzyltoluene.

Unlike the other considered liquid $\mathrm{H}_{2}$ carriers (with the exception of formate salts), the dehydrogenated form of LOHCs must be stored. This means that storage capacity is limited not by the size of the container, but by the amount of LOHC. The bulk price of DBT, which has a maximum $\mathrm{H}_{2}$ storage capacity of $6.2 \%$ (by weight), is approximately $2-4 € / \mathrm{kg}[91,105]$. Consequently, the cost of DBT sufficient to store $1000 \mathrm{t}$ of $\mathrm{H}_{2}$ is around 30-60 M€, excluding the cost of any storage containers and associated equipment (e.g., pumps). Some LOHC material is also lost over time due to thermal degradation and must be replaced, adding further costs [106]; approximately $0.1 \%$ of DBT can be estimated to be lost per storage cycle $[91,104]$. The cost of storage capacity is substantially higher for LOHCs than for other liquid $\mathrm{H}_{2}$ carriers (even for $\mathrm{NH}_{3}$, which requires insulated tanks) and is more comparable to that of underground gaseous $\mathrm{H}_{2}$ storage [24]. Among the LOHCs suggested in the literature, DBT is amongst the cheapest. Based on the simple calculation above, we conclude that while LOHCs with lower enthalpies of dehydrogenation do exist, the higher costs of these may prevent their implementation in an H-DR context.

The H18-DBT/DBT LOHC system has been investigated rather rigorously in recent years, including a successful demonstration of hydrogenation of DBT using "wet" $\mathrm{H}_{2}$ and gas mixtures containing $\mathrm{H}_{2}$ (e.g., syngas) $[107,108]$. The dynamic operation of both hydrogenation and dehydrogenation processes has also been examined. One recent innovation is the use of the same reactor for both DBT hydrogenation and H18-DBT dehydrogenation $[105,109]$. By altering the pressure, it is possible to release (low pressure) or store (high pressure) $\mathrm{H}_{2}$ using a Pt-based catalyst in the same reactor. Using one reactor for both hydrogenation and dehydrogenation lowers the total investment cost and allows for more 
dynamic operation as the reactor rarely has to be heated up from a cold stand-by mode. However, a large-scale reactor of this kind has not yet been demonstrated.

Commercial units for H18-DBT/DBT-based $\mathrm{H}_{2}$ storage, including hydrogenation, dehydrogenation and storage equipment, are available [110]. However, standardized units are relatively low-capacity in terms of steelmaking, with maximum rate capacities of $12 \mathrm{t}$ $\mathrm{H}_{2} / \mathrm{d}$ and $1.5 \mathrm{t} \mathrm{H}_{2} / \mathrm{d}$ for hydrogenation and dehydrogenation units, respectively.

\section{Comparison}

Investment into a $\mathrm{H}_{2}$ storage in the $\mathrm{H}$-DR context is only sensible if the operational and investment costs of the storage do not outweigh savings in the electricity cost of $\mathrm{H}_{2}$ production due to the dynamic operation of electrolyzers. With this in mind, available economic data for the considered $\mathrm{H}_{2}$ carriers are compared in this section. It should be noted that none of these carriers have been used for the storage of $\mathrm{H}_{2}$ at scales suitable for industrial-scale steelmaking. Therefore, the reported values should be regarded as approximate estimates only.

\subsection{Investment Costs}

Storage of $\mathrm{H}_{2}$ in a liquid carrier requires three principal units: (1) a hydrogenation plant, where the carrier is produced; (2) a storage; (3) a dehydrogenation plant, where $\mathrm{H}_{2}$ is released from the liquid carrier. For certain carriers (LOHCs, formate salts), a secondary storage unit for storage of the dehydrogenated carrier is also needed. At present, it is uncertain whether the one-reactor concept is industrially viable for H18-DBT/DBT. Therefore, solutions featuring either one combined reactor or separate hydrogenation and dehydrogenation reactors are both considered.

For these calculations, a standard 0.6 scaling factor has been used for all hydrogenation and dehydrogenation facilities. Storage capacity costs have been assumed to scale linearly. The shown data represent only purchased equipment costs, thus excluding engineering, construction, and contingency costs.

\subsubsection{Hydrogenation Plants}

For most liquid $\mathrm{H}_{2}$ carriers, the hydrogenation plant contributes to the best part of the overall investment cost. One reason for this is the typically high pressures, another is the quite common recycling of unconverted reactants after the reactor, which increases process complexity and size.

The investment cost of the hydrogenation plants depends on their rate capacity. The appropriate hydrogenation rate capacity in the H-DR context is presently uncertain. The choice of installed rate capacity will need to take the development of the electricity market until implementation into account, for instance. Such an optimization is not attempted here. However, hydrogenation rate capacities in excess of the $\mathrm{H}_{2}$ demand of the full-scale $\mathrm{H}-\mathrm{DR}$ process are unlikely due to the high investment costs of electrolyzers. It is also unlikely that the storage must be filled at such rates in order to feed the dehydrogenation process considering the electricity price dynamics.

In Figure 6, the investment costs of the considered hydrogenation plants are seen as a function of their hydrogenation rate capacity. Electrolyzer overcapacity, corresponding to the hydrogenation plant rate capacity, is necessary to feed the plant. Therefore, the investment costs of electrolyzers (or electrolyzer overcapacity) for three cases: 300, 500 and $700 € / \mathrm{kW}$ (assumed to scale, linearly with capacity) are also shown. Electrolyzer investment costs at scales suitable for full-scale H-DR production are presently uncertain, as no such systems have been built. However, values in the range 300-700 $€ / \mathrm{kW}$ may be feasible for scale-up of production volumes [111-114].

Again, it must be emphasized that the uncertainty of the investment costs of these hydrogenation plants is significant. This is particularly true for DBT and FA, where few literature values are available [104]. However, results indicate that the hydrogenation of $\mathrm{N}_{2}$ via the Haber-Bosch process to produce $\mathrm{NH}_{3}$ is the most capital-intensive option, 
followed by FA. A reason for this is the high synthesis pressure and temperature of the Haber-Bosch process compared to the other carriers. The investment cost of a $\mathrm{CO}_{2}$-based $\mathrm{MeOH}$ production plant and a DBT hydrogenation plant appears rather similar, although, again, the values for DBT are uncertain. Reuß et al. (2017) report much lower values, for instance, [115]. Here, we use the values by Hank et al. (2020) due to their recency, and since values are based on "... discussion with an industrial stakeholder and manufacturer of LOHC pilot plants". This result seems to indicate that, while the $\mathrm{MeOH}$ production process is more complex, featuring, e.g., distillation, the higher catalyst cost of DBT hydrogenation more than makes up for this. The potential use of a single reactor for both dehydrogenation of H18-DBT/DBT and hydrogenation of DBT will be discussed in Section 4.1.4.

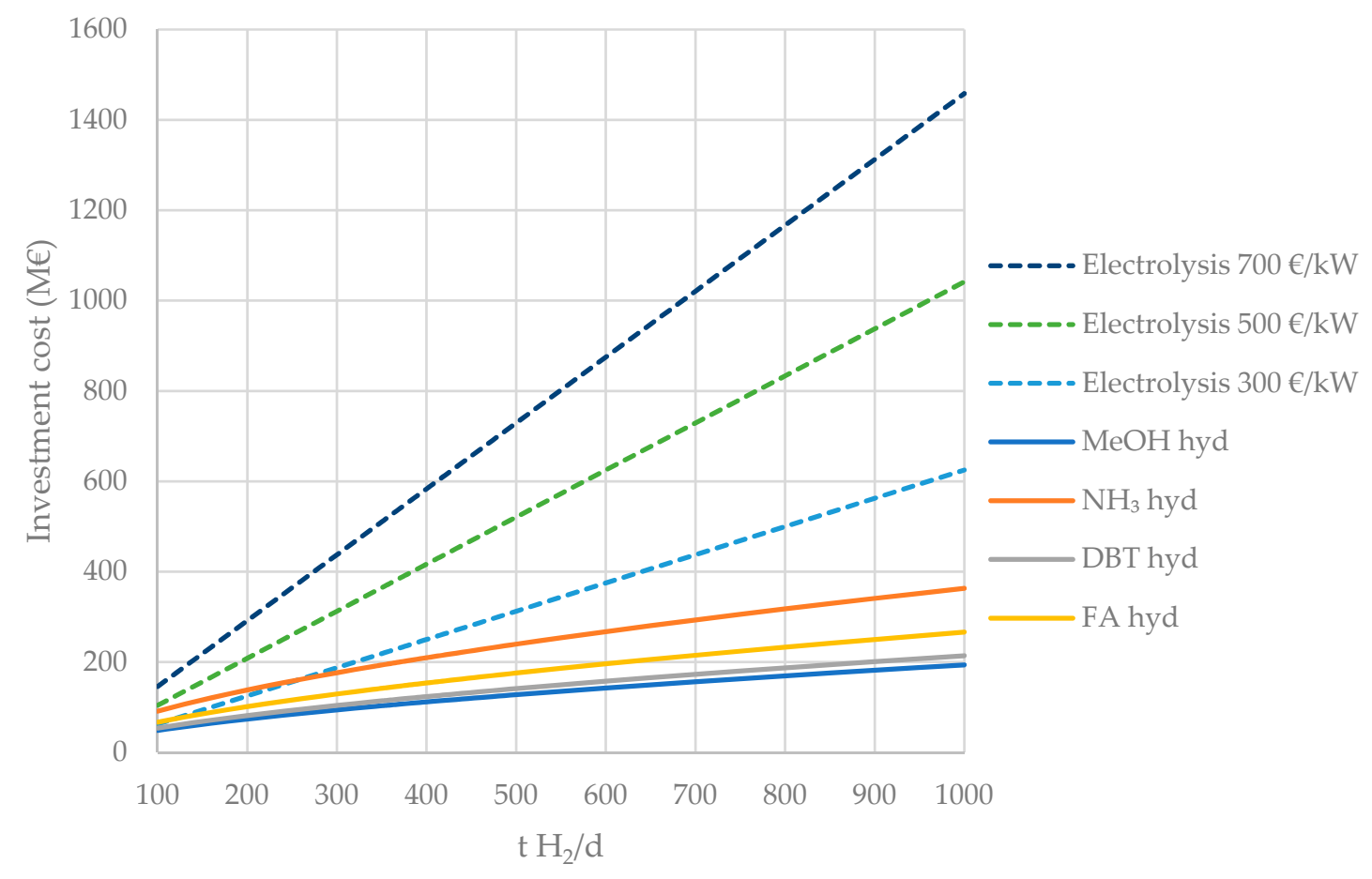

Figure 6. Investment costs of electrolyzer overcapacity and hydrogenation plants for different liquid $\mathrm{H}_{2}$ carriers.

Comparing hydrogenation plant and electrolyzer overcapacity investment costs in Figure 6, it can be seen that electrolyzer overcapacity generally dominates. Generally, it can be concluded that the investment cost of electrolyzer overcapacity has a more significant effect on the overall investment cost than the choice of liquid $\mathrm{H}_{2}$ carrier.

\subsubsection{Dehydrogenation Plants}

Economic data are scarce for large-scale liquid $\mathrm{H}_{2}$ carrier dehydrogenation plants. For instance, no data were retrievable regarding the investment costs of a prospective FA dehydrogenation plant from the scientific literature. For $\mathrm{MeOH}$, data come from a single paper written by employees at Lurgi in 2001. No other economic data were found for largescale $\mathrm{MeOH}$ reforming plants. A similar lack of data is noted for $\mathrm{NH}_{3}$ dehydrogenation. In that case, data come from the previously mentioned "Ammonia to Green Hydrogen Project" report [96], which, again, is the only identified comprehensive reference. For H18-DBT, the same uncertainty as with the investment cost of the DBT hydrogenation plant is noted. Values from Hank et al. (2020) are used for H18-DBT dehydrogenation [91]. Investment costs of dehydrogenation plants are plotted as a factor of their $\mathrm{H}_{2}$ rate capacity in Figure 7 .

Sizing of the dehydrogenation unit is more straightforward compared to the hydrogenation unit. To allow for minimum electrolyzer use during times of high electricity prices, the dehydrogenation plant should be sized to be able to deliver $100 \%$ of the H-DR $\mathrm{H}_{2}$ demand, i.e., it should be possible to operate the entire $\mathrm{H}$-DR process on $\mathrm{H}_{2}$ from the 
dehydrogenation plant. The generally lower investment costs of the dehydrogenation plants compared to hydrogenation (H18-DBT/DBT being the exception) also supports this sizing strategy. Necessary dehydrogenation plant rate capacities to fully supply H-DR processes at various scales is also indicated in Figure 7.

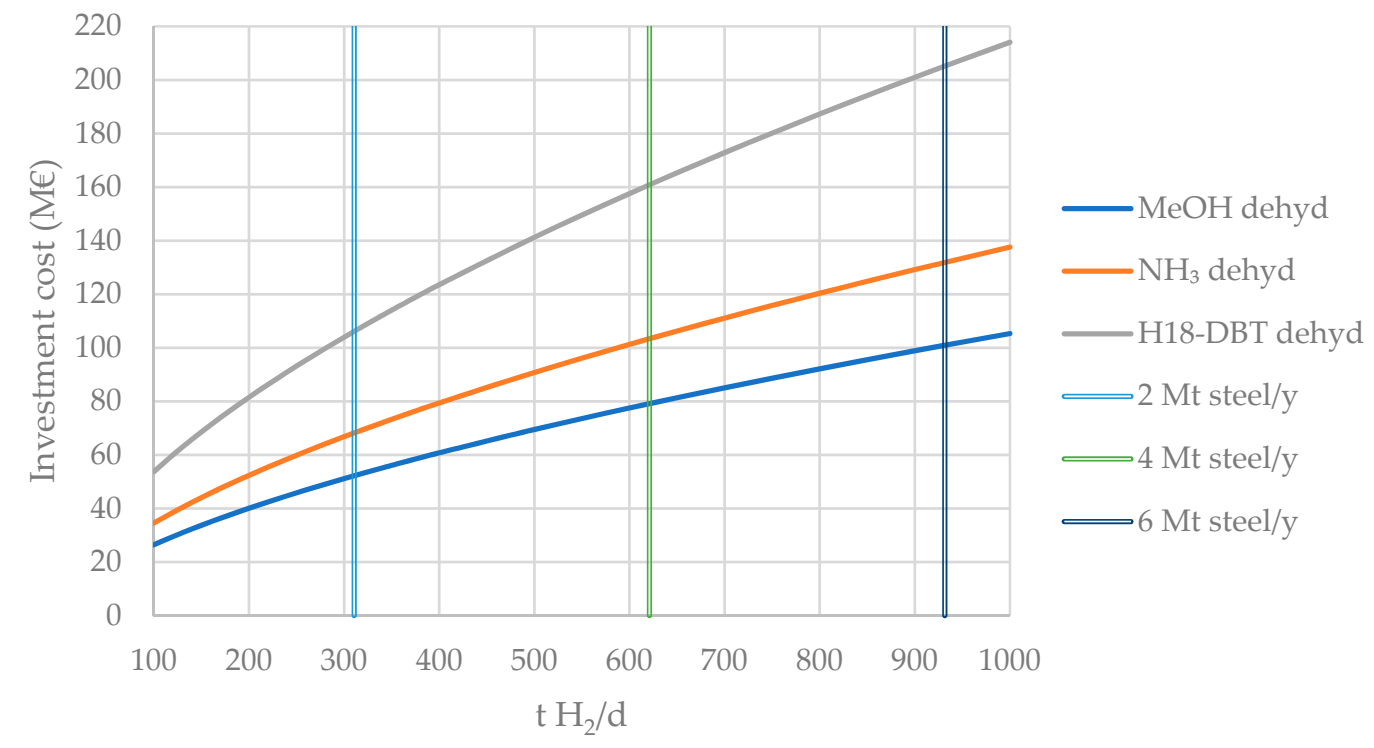

Figure 7. Dehydrogenation plant investment costs for different liquid $\mathrm{H}_{2}$ carriers. $\mathrm{H}_{2}$ demand of dehydrogenation plant to fully supply H-DR process at different production scales also indicated (assumed 0.9 capacity factor, $51 \mathrm{~kg} \mathrm{H} / \mathrm{t}$ steel).

All considered dehydrogenation plants consist of two subprocesses: the actual dehydrogenation reactor and then a separation step to produce near-pure $\mathrm{H}_{2}$. In certain cases, the separation step can be achieved in multiple ways. There is also the question of $\mathrm{H}_{2}$ purity. Fuel-cell-grade purity $\mathrm{H}_{2}$ is not necessary in the $\mathrm{H}$-DR process, but the minimum required $\mathrm{H}_{2}$ purity is presently unknown. In the $\mathrm{NH}_{3}$ dehydrogenation process described above, a cryogenic purification process is applied to generate fuel-cell-grade purity $\mathrm{H}_{2}$. A less complex and lower-cost separation process may be feasible in the H-DR context, lowering the overall costs of the $\mathrm{NH}_{3}$ dehydrogenation plant. For the other carriers, separation is more straightforward, either via simple condensation (H18-DBT/DBT), or PSA $(\mathrm{MeOH})[98,116]$.

In terms of dehydrogenation, $\mathrm{MeOH}$ appears to be the lowest investment cost option by a significant margin. The reasons for this are foremost the relatively low process temperature (compared to $\mathrm{NH}_{3}$ ), cheap catalyst (compared to H18-DBT) and process simplicity. H18-DBT dehydrogenation is found to be the most expensive option due to catalyst costs (noting, again, the uncertainty of H18-DBT/DBT economic data). The differences in investment costs are considerable: at $300 \mathrm{t} \mathrm{H}_{2}$ / d rate capacity, the $\mathrm{MeOH}$ dehydrogenation plant is approximately $30 \%$ and $100 \%$ less expensive than options based on $\mathrm{NH}_{3}$ or H18-DBT, respectively.

\subsubsection{Storage Units}

The cost of $\mathrm{H}_{2}$ storage capacity differs greatly among the considered liquid $\mathrm{H}_{2}$ carriers. $\mathrm{MeOH}$ can be stored in conventional steel storage tanks, similar to those used for storing oil. FA is, in high concentrations, corrosive due to its acidity. This corrosiveness means that pure FA must be stored in stainless steel tanks, which increases material costs by roughly $30 \%$ compared to carbon steel (lower-concentration FA solutions can be stored in polyethylene, polypropylene or rubber-lined carbon steel vessels.) $[79,117,118] . \mathrm{NH}_{3}$ is most commonly stored in liquid form in insulated tanks (boiling point $-33^{\circ} \mathrm{C}$ ), which increases costs, although the volumetric $\mathrm{H}_{2}$ storage density is high. The situation is most unique for H18-DBT/DBT. Firstly, both hydrogenated and dehydrogenated forms must 
be stored, necessitating at least two storage tanks. Secondly, the LOHC material itself must also be purchased in sufficient amounts. As a result, $\mathrm{H}_{2}$ storage capacity is relatively expensive for LOHCs, as can be seen in Table 1.

Table 1. Investment cost of storage for different liquid $\mathrm{H}_{2}$ carriers [91].

\begin{tabular}{ccc}
\hline Liquid $\mathbf{H}_{\mathbf{2}}$ Carrier & $\boldsymbol{\epsilon} / \mathbf{t}$ Carrier & $\boldsymbol{\epsilon / \mathbf { t ~ } \mathbf { H } _ { \mathbf { 2 } }}$ \\
\hline $\mathrm{MeOH}$ & $75 € / \mathrm{t} \mathrm{MeOH}$ & 397 \\
$\mathrm{FA}$ & $63 € / \mathrm{t} \mathrm{FA}$ & $1439^{*}$ \\
$\mathrm{NH}_{3}$ & $350 € / \mathrm{t} \mathrm{NH}$ & 1977 \\
$(\mathrm{H} 18-) \mathrm{DBT}$ & $68 € / \mathrm{t}(\mathrm{H} 18-) \mathrm{DBT}$ for storage & $34,452^{\#}$ \\
& tanks, $2 € / \mathrm{kg} \mathrm{DBT}$ material & \\
\hline
\end{tabular}

${ }^{*}$ Based on $\mathrm{MeOH}$ storage cost, adapted for stainless steel (factor 1.3) and differences in liquid density compared to $\mathrm{MeOH}(792 / 1220=0.65)$. \# Includes two storage tanks (both at $68 € / \mathrm{t}(\mathrm{H} 18-) \mathrm{DBT}$ ) and DBT material (at $2 € / \mathrm{kg}$ DBT).

\subsubsection{Total Investment Costs}

The overall investment costs for different liquid $\mathrm{H}_{2}$ carriers as a function of storage capacity is seen in Figure 8. The comparison is based on an H-DR process producing $2 \mathrm{Mt}$ of DRI per year. Two cases with different hydrogenation rate capacities, equivalent to electrolyzer overcapacities of $25 \%$ and $75 \%$, are shown for each carrier. The only exception is for H18-DBT/DBT utilizing the same reactor for hydrogenation and dehydrogenation (the one reactor (OR) concept) where only one case (100\% overcapacity) is shown. FA is not included, as no investment costs of its dehydrogenation process could be found in the literature.

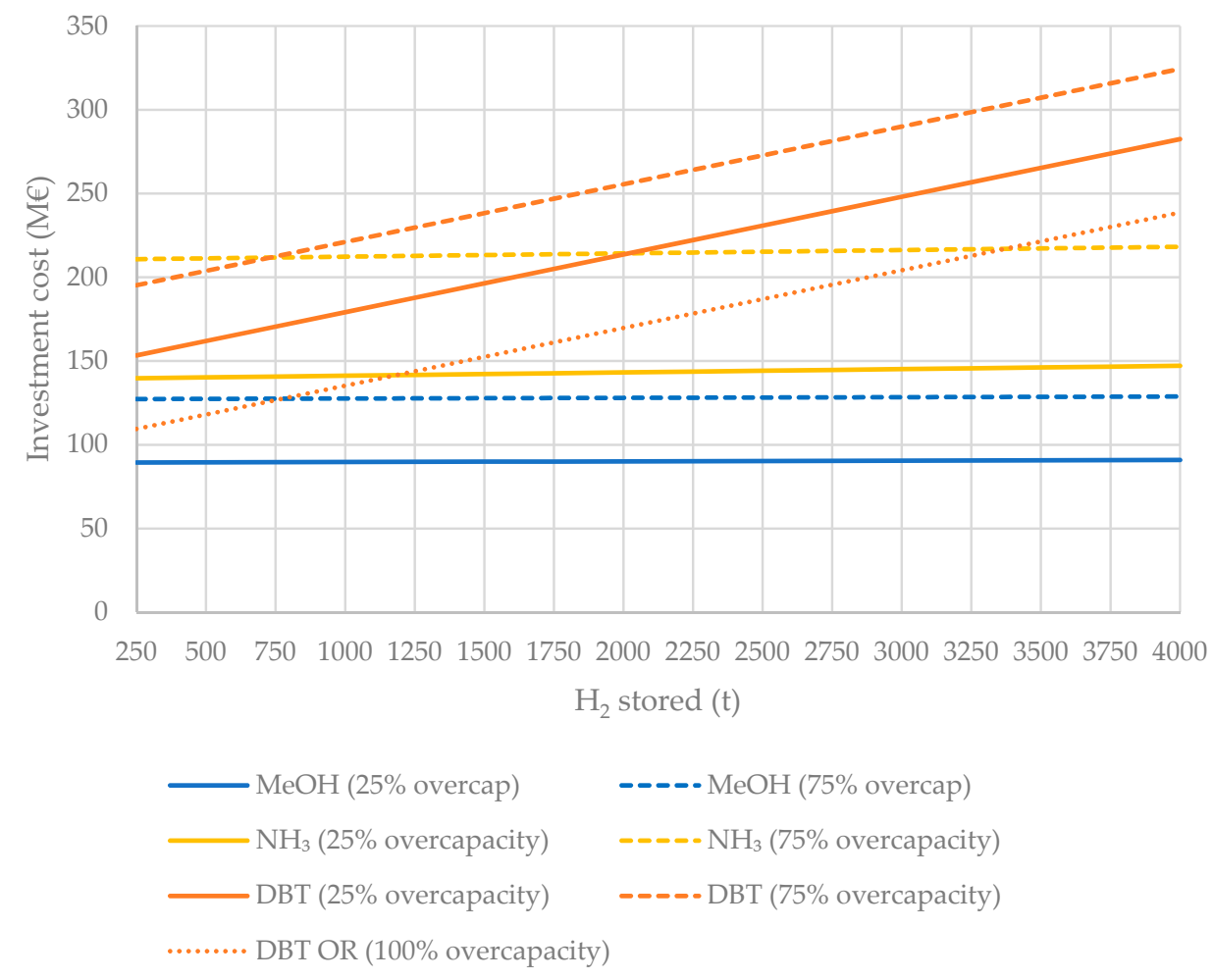

Figure 8. Total investment costs of liquid $\mathrm{H}_{2}$ carrier-based $\mathrm{H}_{2}$ storage systems $(\mathrm{OR}=$ one reactor concept).

Several conclusions can be drawn from Figure 8. Firstly, the cost of storage capacity is nearly negligible for $\mathrm{MeOH}$ and $\mathrm{NH}_{3}$, but not for H18-DBT/DBT. Consequently, $\mathrm{MeOH}$ and $\mathrm{NH}_{3}$ appear to become better options at larger storage capacities. Secondly, $\mathrm{MeOH}$ is, in nearly all cases, the lowest-cost liquid carrier option. The only exception is for the case 
of low storage capacities, where the OR H18-DBT/DBT system potentially reaches lower investment costs due to use of a single facility for both hydrogenation and dehydrogenation.

\subsection{Operational Costs}

The purpose of a $\mathrm{H}_{2}$ storage in the H-DR context is to lower the electricity cost of $\mathrm{H}_{2}$ production via exploiting differences in electricity price over time, as more $\mathrm{H}_{2}$ can be produced at lower electricity prices and less at high electricity prices. The operating costs of the storage, i.e., mainly costs of additional electricity and heat, determine how much the electricity price must increase between the storage and release of $\mathrm{H}_{2}$ for storage to reach a positive contribution margin and become economically sensible. The capacity factor and overall profitability of the storage is then dependent on how often such sufficiently large electricity price differences appear, i.e., on the electricity market dynamics. In practice, additional factors such as electricity price forecast accuracy, storage capacity limitations, hydrogenation and dehydrogenation process dynamics, and electrolyzer degradation also come into play. Therefore, the profitability of investment into a $\mathrm{H}_{2}$ storage can only be evaluated via simulation. Nevertheless, consideration of the operational costs of the storage along the historical electricity price duration curves can give an indication of how often and how profitably a storage can be operated.

As mentioned previously, the operational costs of $\mathrm{H}_{2}$ storage in these liquid carriers is largely made up of the electricity demand of the hydrogenation process and the heat demand of the dehydrogenation process. Relevant values for these processes are seen in Table 2.

Table 2. Electricity and heat demands of dehydrogenation and hydrogenation processes.

\begin{tabular}{|c|c|c|c|}
\hline Liquid $\mathrm{H}_{2}$ Carrier & $\begin{array}{c}\text { Electricity Demand } \\
\text { Hydrogenation }\left(\mathrm{kWh} / \mathrm{kg} \mathrm{H}_{2}\right)\end{array}$ & $\begin{array}{l}\text { Heat Demand Dehydrogenation } \\
\left(\mathrm{kWh} / \mathrm{kg} \mathrm{H}_{2}\right)\end{array}$ & $\begin{array}{c}\text { Temperature } \\
\text { Dehydrogenation }\end{array}$ \\
\hline $\mathrm{MeOH}$ & $<0.0-0.9$ & $2.5-6.9^{\#}$ & $64 \%<100{ }^{\circ} \mathrm{C}$, rest $>200{ }^{\circ} \mathrm{C}$ \\
\hline FA & $3.6-6.7(+16-63$ heat $)$ & $2.8-9.1$ & $<100^{\circ} \mathrm{C}$ \\
\hline $\mathrm{NH}_{3}$ & $3.4-6.2$ & $14.3(-1.6$ electricity generated $)$ & $>500{ }^{\circ} \mathrm{C}$ \\
\hline H18-DBT/DBT & 0.4 & $11.5^{\mathrm{a}}$ & $>300^{\circ} \mathrm{C}$ \\
\hline
\end{tabular}

${ }^{\#} 64 \%$ of this heat is for evaporation of $\mathrm{MeOH}$ and $\mathrm{H}_{2} \mathrm{O}$ at $<100{ }^{\circ} \mathrm{C}$. Reaction heat assumed to be supplied with $90 \%$ efficiency. Lower value $\left(2.5 \mathrm{kWh} / \mathrm{kg} \mathrm{H}_{2}\right)$ assumes that evaporation heat is freely available from the H-DR process. ${ }^{a}$ Based on value by Eypasch et al., but corrected to use the proper heat of dehydrogenation of H18-DBT [119].

For hydrogenation, the use of $\mathrm{NH}_{3}$, and especially FA, appears to be the most energyintensive options. The large heat demand of FA production, mainly due to separation processes (as mentioned in Section 3.3.2), is also of note (all other hydrogenation processes have a heat surplus). Unfortunately, for low-temperature electrolyzers, the surplus heat would not be sufficient to power the FA production process, both in terms of amount and temperature level $\left(100-200^{\circ} \mathrm{C}\right)$. Therefore, it is likely that external heat must be supplied to an FA production process. In contrast, the H18-DBT/DBT and $\mathrm{MeOH}$ routes require relatively small amounts of electricity for hydrogenation. This is due to the relatively low reactor pressures. The heat generated via the exothermic hydrogenation reactions is assumed to be utilized within the overall hydrogenation processes, as heat integration is likely challenging considering the intermittent operation.

For dehydrogenation, FA is likely the least heat-intensive option, especially considering the low reaction temperature $\left(<100{ }^{\circ} \mathrm{C}\right)$, followed by $\mathrm{MeOH}$. In addition, a large part of the heat demand of $\mathrm{MeOH}$ dehydrogenation (around 64\%) is at a relatively low temperature. The actual reaction heat of MSR (at $>200{ }^{\circ} \mathrm{C}$ ) could theoretically be covered by DRI cooling, which appears an attractive option. However, the supply of low-temperature heat in the cases of FA and $\mathrm{MeOH}$ may still constitute a challenge, especially considering the previously mentioned poor temporal match between FA or MeOH dehydrogenation and electrolyzer operation in the H-DR process.

The dehydrogenation of $\mathrm{NH}_{3}$ or H18-DBT requires significant heat at elevated temperatures. Heat integration within the H-DR process appears unlikely to be sufficient in 
these cases. Instead, this heat should preferably be supplied via combustion of part of the released $\mathrm{H}_{2}$, electricity or external fuels; if part of released $\mathrm{H}_{2}$ is combusted to generate this heat, more than $35 \%$ of the released $\mathrm{H}_{2}$ is consumed [44,47].

Using the data in Table 2, it is possible to estimate the added cost of storage $\left(\Delta C_{\text {storage }}\right.$ $\left.\left(€ / \mathrm{kg} \mathrm{H}_{2}\right)\right)$ in the liquid carriers due to additional OPEX compared to the case without storage, given an electrolysis efficiency $\left(\mathrm{P}_{\text {elec }}\right)$, a "low" electricity price $\left((€ / \mathrm{MWh})_{\mathrm{P}, \mathrm{low}}\right)$ for when $\mathrm{H}_{2}$ is stored, and a heat price during hydrogenation $\left((€ / \mathrm{MWh})_{\mathrm{Q}}\right.$, only applicable for the FA case).

$$
\Delta C_{\text {storage }}=\left(\frac{\left(\mathrm{P}_{\text {elec }}+\mathrm{P}_{\text {hyd }}\right) \cdot\left(\frac{€}{\mathrm{MWh}}\right)_{\mathrm{P}, \mathrm{low}}}{1-\frac{\mathrm{Q}_{\text {dehyd }}}{\mathrm{LHV}_{\mathrm{H}_{2}}}}\right)+\mathrm{Q}_{\text {hyd }} \cdot\left(\frac{€}{\mathrm{MWh}}\right)_{\mathrm{Q}}-\mathrm{P}_{\text {elec }} \cdot\left(\frac{€}{\mathrm{MWh}}\right)_{\mathrm{P}, \mathrm{low}}
$$

Equation (6) assumes that the heat for the dehydrogenation process is supplied via combustion of part of the released $\mathrm{H}_{2}$ (with no heat losses). This means that the electricity price during the hydrogenation process $\left((€ / \mathrm{MWh})_{\mathrm{P}, \text { low }}\right)$ becomes a very important parameter, as the combustion of $\mathrm{H}_{2}$ produced at a relatively high electricity price constitutes expensive heat. Note that the electricity supply for dehydrogenation processes is not included in Equation (6), as these are generally small. It is also assumed that it is not viable to generate electricity from an intermittently operated $\mathrm{NH}_{3}$ dehydrogenation plant. An electrolysis efficiency of $50 \mathrm{kWh} / \mathrm{kg} \mathrm{H}_{2}$ and a hydrogenation heat price of $20 € / \mathrm{MWh}$ yields the results in Figure 9. Two cases have been plotted for all carriers except DBT: one based on the most optimistic values in Table 2 ("LOW") and one on the most pessimistic ("HIGH"). The difference between LOW and HIGH is particularly large for FA, reflecting the relative uncertainty of its application.

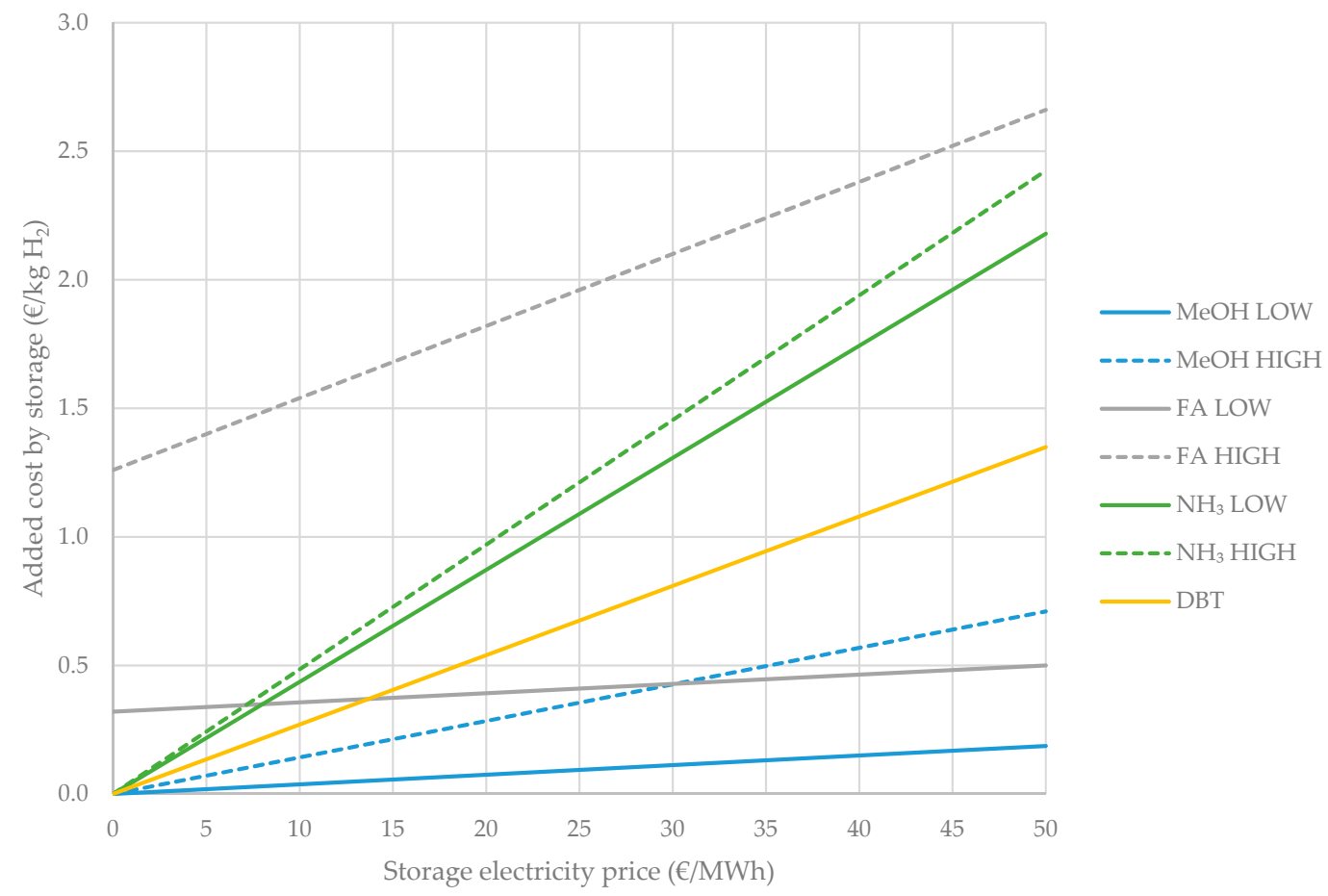

Figure 9. Added cost of storage for liquid $\mathrm{H}_{2}$ carriers. Heat for dehydrogenation is supplied via combustion of part of released $\mathrm{H}_{2}$, heat price for FA hydrogenation $20 € /$ MWh (other hydrogenation processes are exothermic).

As can be seen, $\mathrm{MeOH}$ turns out to be the best-performing option for nearly the entire range of considered storage electricity prices due to its relatively low associated electricity demand of hydrogenation and heat demand of dehydrogenation (even in the worst-case scenario). The negative effect of the large heat demand of FA production, 
particularly in the pessimistic case, can be clearly seen in Figure 8: even for a storage electricity price of $0 € / \mathrm{MWh}$, storage of $\mathrm{H}_{2}$ in FA adds $0.3-1.3 € / \mathrm{kg}$ to the cost of $\mathrm{H}_{2}$. The large heat demand of $\mathrm{NH}_{3}$ and $\mathrm{H} 18$-DBT dehydrogenation renders the use of these carriers particularly unattractive for higher storage electricity prices, as a large share of the stored $\mathrm{H}_{2}$ must be combusted. Note that the results in Figure 9 do not include the investment cost of the storages or electrolyzer overcapacity. The effects of limited load flexibility are also excluded. Therefore, the real added costs of storage are larger.

\subsection{Load Flexibility}

For $\mathrm{H}_{2}$ storage in liquid carriers to be practical, it must be possible to produce and dehydrogenate these in a dynamic manner. As seen in Figure 9, ideally, $\mathrm{H}_{2}$ is overproduced and stored only when the electricity price is relatively low, while the stored $\mathrm{H}_{2}$ is only utilized when the electricity price is relatively high (when it is expensive to produce "new" $\mathrm{H}_{2}$ via electrolysis) [56]. Chemical processes have conventionally not been operated according to this logic. Indeed, as the prices of typical feedstocks, e.g., oil, coal and natural gas, varies slowly in comparison to that of electricity, there has been no strong incentive to maximize the load window and operational flexibility of industrial chemical processes. The focus has instead generally been on increasing the process efficiency at nominal load and to ensure that the process can operate at nominal load as regularly as possible $[120,121]$. Therefore, data on process flexibility are often scarce, uncertain or unknown for such processes. However, this has been changing in recent years with the increasing interest in large-scale chemical processes based on a feed of $\mathrm{H}_{2}$ produced via electrolysis.

In an H-DR process, a low minimum load is important for both hydrogenation and dehydrogenation processes, as a high minimum load in either end necessitates the production of $\mathrm{H}_{2}$ during times of relatively high electricity prices. However, as the nominal capacity of the dehydrogenation process will generally be higher than that of the hydrogenation process (due to the high investment cost of electrolyzers and electricity price dynamics), its minimum load becomes especially important. On the hydrogenation side, the adverse effects of a high minimum load may be partially managed via the integration of a buffer storage of gaseous $\mathrm{H}_{2}$, although this adds investment costs. Such a buffer storage can be used to supply $\mathrm{H}_{2}$ to the hydrogenation process during high electricity prices, allowing the electrolyzers to then be turned off (or operated at their minimum load).

Amongst the liquid $\mathrm{H}_{2}$ carriers considered here, the largest body of process flexibility data exists for $\mathrm{MeOH}$ and $\mathrm{NH}_{3}$. However, even here the reported values have generally not been demonstrated in practice, at least not consistently over extended periods in full-scale facilities. For $\mathrm{MeOH}$ production with $\mathrm{H}_{2}$ and $\mathrm{CO}_{2}$, minimum load values in the range of $10-20 \%$ of the nominal load have been reported $[56,63,122]$. Maximum ramp rates from $20 \% / \mathrm{h}$ to up to minimum to full load within minutes appear possible $[56,62,123]$. Data on the dynamic operation of industrial-scale $\mathrm{MeOH}$ reformers are scarce. However, the possibilities for dynamic $\mathrm{MeOH}$ dehydrogenation appears to be good considering the relatively low required temperatures, the moderate heat demand and relative success in developing small-scale rapid-start-up $\mathrm{MeOH}$ reformers for automotive applications [67,124,125]. PSA units have short start-up times as well [89]. Electrically heated $\mathrm{MeOH}$ reformers should be able to achieve near-instantaneous start-up [47].

Dynamic operation of the Haber-Bosch is receiving increasing interest in the literature. Current Haber-Bosch processes typically operate with a minimum load of around 50-60\% and a maximum ramp rate of $20 \% / \mathrm{h}[126,127]$. However, minimum loads of around $20-30 \%$ or lower should be achievable, e.g., via increasing the concentration of inert content in the reactor loop, although such methods do increase the specific electricity consumption of the $\mathrm{NH}_{3}$ synthesis somewhat due to increased compression work [127-129]. One possibility to achieve this is via limiting the purge stream during operation at partial load (this method of controlling the Haber-Bosch process load has been patented [127]) [128]. Cold start-up of the Haber-Bosch process normally takes multiple days. 
Large-scale $\mathrm{NH}_{3}$ dehydrogenation has, as already mentioned, rarely been considered in the literature. However, the process is rather similar to conventional steam methane reforming (SMR) [96]. Industrial SMR plants typically operate continuously with minimum loads of at least 30\%; start-up requires at least a couple of hours [130]. The subsequent cryogenic separation step is typically not very dynamic either [89]. As for $\mathrm{MeOH}$, electric heating of the $\mathrm{NH}_{3}$ dehydrogenation process may facilitate faster dynamics [44].

Commercial H18-DBT hydrogenation and DBT dehydrogenation processes can achieve minimum loads of $50 \%$ of the nominal rate per supplier data [131]. The one reactor DBT concept would, by its nature, allow for $0 \%$ minimum loads (as the reactor is completely switched over from hydrogenation to dehydrogenation or vice versa), although the minimum load of the reactor in either mode is presently uncertain [109].

No data on the dynamics of $\mathrm{CO}_{2}$-based FA production or FA dehydrogenation could be found in the literature. Nevertheless, low minimum loads and relatively fast startup could be realistic considering the relatively low temperatures involved, especially for FA dehydrogenation.

\section{Conclusions}

The application of liquid $\mathrm{H}_{2}$ carriers in the context of large-scale $\mathrm{H}-\mathrm{DR}$ processes has been investigated. The main advantage of storage of $\mathrm{H}_{2}$ in such liquid carriers rather than gaseous underground storage is the far lower cost of storage capacity. Four of the most intensively investigated liquid $\mathrm{H}_{2}$ carriers where considered: $\mathrm{MeOH}, \mathrm{FA}, \mathrm{NH}_{3}$ and $\mathrm{H} 18$ DBT/DBT. The technological readiness of the application of these carriers differs in, e.g., an $\mathrm{H}$-DR context. $\mathrm{MeOH}$ and $\mathrm{NH}_{3}$ are the most developed carriers, in particular with regard to the hydrogenation process, as these are largely based on current conventional industrial processes. For H18-DBT/DBT, commercial equipment does exist, but only at small scales as of yet. The use of FA as a $\mathrm{H}_{2}$ carrier at large scales remains to be demonstrated, in particular its direct production via the hydrogenation of $\mathrm{CO}_{2}$.

The application of a liquid $\mathrm{H}_{2}$ carrier requires a hydrogenation plant, a carrier storage and a dehydrogenation plant. The investment and operational costs of these units differs significantly from carrier to carrier. Based on a review of the literature data, it is concluded that the $\mathrm{MeOH}$-based system should achieve the lowest investment costs overall for a given electrolyzer overcapacity and $\mathrm{H}$-DR process $\mathrm{H}_{2}$ demand. The $\mathrm{NH}_{3}$ route suffers from the high capital-intensity of the Haber-Bosch process, while the investment cost of the H18-DBT/DBT system is weighted down by the need to store the dehydrogenated carrier. For small storage capacities $\left(<750 \mathrm{t} \mathrm{H}_{2}\right)$, a version of the H18-DBT route utilizing the same reactor for both hydrogenation and dehydrogenation may be competitive at relatively low $\mathrm{H}_{2}$ storage capacities. The overall investment cost of a FA-based system remains uncertain, especially for a large-scale dehydrogenation plant.

In terms of operational costs, $\mathrm{MeOH}$ again performs the best, particularly when lowtemperature heat $\left(<100{ }^{\circ} \mathrm{C}\right)$ is available from the $\mathrm{H}$-DR process. $\mathrm{NH}_{3}$ and $\mathrm{H} 18$-DBT require significantly more high-temperature heat for dehydrogenation, which limits their appeal in an H-DR process. Uniquely, the operational costs of the FA route are dominated by the potentially high heat demand of the hydrogenation process caused by the energy-intensive separation steps. If large amounts of heat at $<180{ }^{\circ} \mathrm{C}$ are available at low cost $(<5 € / \mathrm{MWh})$, FA may be competitive with $\mathrm{MeOH}$ in terms of operational costs. However, this scenario does not appear likely.

Beyond investment and operational costs, the economic viability of liquid $\mathrm{H}_{2}$ carriers in the H-DR context depends on the load flexibility of the hydrogenation and dehydrogenation processes. This is a growing research field and the current available data are limited. Nevertheless, the dynamic operation of the $\mathrm{MeOH}$ and $\mathrm{NH}_{3}$ production processes appears feasible, with minimum loads in the ranges of $10-20 \%$ and $20-30 \%$ for $\mathrm{MeOH}$ and $\mathrm{NH}_{3}$, respectively. $\mathrm{MeOH}$ dehydrogenation has been proven to be a flexible process at small scales, e.g., onboard vehicles, and operates at a relatively low temperature, which facilitates quick start-up. Nevertheless, the load flexibility of an industrial-scale $\mathrm{MeOH}$ reformer 
remains to be determined. The high temperatures necessary for the $\mathrm{NH}_{3}$ dehydrogenation process will limit its load window; the similar SMR process has a typical minimum load of 30\%. Currently available DBT hydrogenation and H18-DBT dehydrogenation plants have minimum loads of $50 \%$ per supplier data. The main relative advantages and disadvantages of the considered liquid $\mathrm{H}_{2}$ carriers, as well as the main questions to be answered before their commercialization is possible, are summarized in Table 3.

Table 3. Summary of advantages, disadvantages and main questions left to be answered before large-scale employment of the considered liquid $\mathrm{H}_{2}$ carriers.

\begin{tabular}{|c|c|c|c|}
\hline Liquid $\mathrm{H}_{2}$ Carrier & Advantages & Disadvantages & $\begin{array}{l}\text { Questions to Resolve before } \\
\text { Large-Scale Deployment }\end{array}$ \\
\hline $\mathrm{MeOH}$ & $\begin{array}{ll}\text { - } & \text { High } \mathrm{H}_{2} \text { storage density. } \\
\text { Relatively } \\
\text { low-temperature, low-heat } \\
\text { demand dehydrogenation. } \\
\text { Relatively low-pressure } \\
\text { hydrogenation. }\end{array}$ & $\begin{array}{l}\text { - Large heat demand of } \\
\text { evaporation of } \mathrm{MeOH} \text { and } \mathrm{H}_{2} \mathrm{O} \text {. } \\
\mathrm{CO}_{2} \text { may be expensive from } \\
\text { certain sources. }\end{array}$ & $\begin{array}{l}\text { - } \quad \text { Load flexibility. } \\
\text { Optimal process design } \\
\text { without distillation. } \\
\text { Optimal supply of } \mathrm{CO}_{2} \text {. }\end{array}$ \\
\hline FA & $\begin{array}{l}\text { Low-temperature } \\
\text { dehydrogenation possible. } \\
\text { - } \quad \text { High-pressure } \\
\text { dehydrogenation possible. }\end{array}$ & $\begin{array}{l}\text { - } \quad \text { Low } \mathrm{H}_{2} \text { storage density. } \\
\text { endrogenation is } \\
\text { - } \mathrm{CO}_{2} \text { may be expensive from } \\
\text { certain sources. }\end{array}$ & 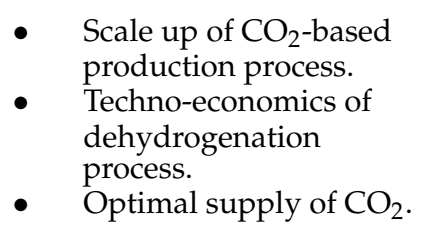 \\
\hline $\mathrm{NH}_{3}$ & $\begin{array}{ll}\text { - } & \text { High } \mathrm{H}_{2} \text { storage density. } \\
\text { - } & \text { Practically endless supply } \\
\text { of } \mathrm{N}_{2} \text {. } \\
\text { - Well-established } \\
\text { production process. }\end{array}$ & $\begin{array}{l}\text { - } \quad \begin{array}{l}\text { Energy-intensive } \\
\text { dehydrogenation. }\end{array} \\
\text { - } \quad \text { Must be liquefied, stored in } \\
\text { insulated containers. } \\
\text { - Haber-Bosch process capital } \\
\text { intensive, high pressures } \\
\text { needed. }\end{array}$ & $\begin{array}{l}\text { - } \quad \text { Load flexibility. } \\
\text { Optimal catalyst for and } \\
\text { design of } \\
\text { dehydrogenation } \\
\text { process. }\end{array}$ \\
\hline H18-DBT/DBT & $\begin{array}{ll}-\quad & \text { Near-pure } \mathrm{H}_{2} \text { released. } \\
-\quad & \text { Low process complexity. } \\
\text { - } & \text { Relatively low-pressure } \\
& \text { hydrogenation. }\end{array}$ & $\begin{array}{l}\text { Dehydrogenated LOHC must be } \\
\text { stored. } \\
\text { - } \quad \text { LOHC material is expensive. } \\
\text { Large heat demand of } \\
\text { dehydrogenation. }\end{array}$ & $\begin{array}{l}\text { - } \quad \text { Load flexibility } \\
\text { - } \quad \text { Scale-up of processes } \\
\text { - Catalyst costs at larger } \\
\text { scales. }\end{array}$ \\
\hline
\end{tabular}

We conclude that $\mathrm{MeOH}$ is the most attractive candidate for integration into a largescale $\mathrm{H}-\mathrm{DR}$ processes amongst the considered liquid $\mathrm{H}_{2}$ carriers. $\mathrm{MeOH}$ is especially advantageous for large $\mathrm{H}_{2}$ storage capacities. Nevertheless, significant hurdles for the implementation of this carrier remain, mainly related to the appropriate supply of heat for dehydrogenation and $\mathrm{CO}_{2}$ for hydrogenation.

Funding: The work has been conducted as part of the HYBRIT research project RP-1. I gratefully acknowledge financial support from the Swedish Energy Agency.

Conflicts of Interest: The author declares no conflict of interest.

\section{References}

1. Pérez-Fortes, M.; Moya, J.A.; Vatopoulos, K.; Tzimas, E. $\mathrm{CO}_{2}$ Capture and Utilization in Cement and Iron and Steel Industries. Energy Procedia 2014, 63, 6534-6543. [CrossRef]

2. Allen, M.; Antwi-Agyei, P.; Aragon-Durand, F.; Babiker, M.; Bertoldi, P.; Bind, M.; Brown, S.; Buckeridge, M.; Camilloni, I.; Cartwright, A. Technical Summary: Global Warming of $1.5^{\circ} \mathrm{C}$. An IPCC Special Report on the Impacts of Global Warming of $1.5^{\circ} \mathrm{C}$ above pre-Industrial Levels and Related Global Greenhouse Gas Emission Pathways, in the Context of Strengthening the Global Response to the Threat of Climate Change, Sustainable Development, and Efforts to Eradicate Poverty; Intergovernmental Panel on Climate Change: Geneve, Switzerland, 2019. 
3. IPCC Climate Change. Mitigation of climate change. In Contribution of Working Group III to the Fifth Assessment Report of the Intergovernmental Panel on Climate Change; Cambridge University Press: London, UK, 2014.

4. Sasiain, A.; Rechberger, K.; Spanlang, A.; Kofler, I.; Wolfmeir, H.; Harris, C.; Bürgler, T. Green Hydrogen as Decarbonization Element for the Steel Industry. BHM Berg Hüttenmännische Mon. 2020, 165, 232-236. [CrossRef]

5. Pei, M.; Petäjäniemi, M.; Regnell, A.; Wijk, O. Toward a Fossil Free Future with HYBRIT: Development of Iron and Steelmaking Technology in Sweden and Finland. Metals 2020, 10, 972. [CrossRef]

6. Material Economics. Industrial Transformation 2050: Pathways to Net-Zero Emissions from EU Heavy Industry; Material Economics: Stockholm, Sweden, 2019.

7. Ryan, N.A.; Miller, S.A.; Skerlos, S.J.; Cooper, D.R. Reducing $\mathrm{CO}_{2}$ Emissions from US Steel Consumption by $70 \%$ by 2050 . Environ Sci. Technol. 2020, 54, 14598-14608. [CrossRef]

8. HYBRIT. Final Report HYBRIT—Hydrogen Breakthrough Ironmaking Technology; Energimyndigheten: Stockholm, Sweden, 2018.

9. Béchara, R.; Hamadeh, H.; Mirgaux, O.; Patisson, F. Optimization of the iron ore direct reduction process through multiscale process modeling. Materials 2018, 11, 1094. [CrossRef]

10. Battle, T.; Srivastava, U.; Kopfle, J.; Hunter, R.; McClelland, J. The Direct Reduction of Iron. In Treatise on Process Metallurgy; Elsevier: Amsterdam, The Netherlands, 2014; pp. 89-176.

11. Anameric, B.; Kawatra, S.K. Properties and features of direct reduced iron. Miner. Process. Extr. Metall. Rev. 2007, $28,59-116$. [CrossRef]

12. Liu, B.N.; Li, Q.; Zou, Z.S.; Yu, A.B. Discussion on chemical energy utilisation of reducing gas in reduction shaft furnace. Ironmak. Steelmak. 2014, 41, 568-574. [CrossRef]

13. Hübner, T.; Guminski, A.; Pichlmaier, S.; Höchtl, M.; Roon, S. European Steel with Hydrogen; Forschungsstelle für Energiewirtschaft: Munich, Germany, 2020.

14. Lundgren, J.; Ekbom, T.; Hulteberg, C.; Larsson, M.; Grip, C.-E.; Nilsson, L.; Tunå, P. Methanol production from steel-work off-gases and biomass based synthesis gas. Appl. Energy 2013, 112, 431-439. [CrossRef]

15. Nuber, D.; Eichberger, H.; Rollinger, B. Circored fine ore direct reduction. Millen. Steel 2006, 2006, 37-40.

16. Holappa, L. A general vision for reduction of energy consumption and $\mathrm{CO}_{2}$ emissions from the steel industry. Metals 2020, 10, 1117. [CrossRef]

17. Tang, J.; Chu, M.-S.; Li, F.; Feng, C.; Liu, Z.-G.; Zhou, Y.-S. Development and progress on hydrogen metallurgy. Int. J. Miner. Metall. Mater. 2020, 27, 713-723. [CrossRef]

18. ArcelorMittal. Hydrogen-Based Steelmaking to Begin in Hamburg. 2021. Available online: https:/ / corporate.arcelormittal.com/ media/case-studies/hydrogen-based-steelmaking-to-begin-in-hamburg (accessed on 22 January 2021).

19. Thyssenkrupp. Green Hydrogen for Steel Production: RWE and Thyssenkrupp Plan Partnership. 2020. Available online: https:/ / www.thyssenkrupp.com/en/newsroom/press-releases/pressdetailpage/green-hydrogen-for-steel-production-rwe-and-thyssenkrupp-plan-partnership-82841 (accessed on 22 January 2021).

20. Varriale, L. Germany's Thyssenkrupp to Build DRI Plant Run on Hydrogen for Green Steel Production. 2020. Available online: https:/ / www.spglobal.com/platts/en/market-insights/latest-news/metals/082820-germanys-thyssenkrupp-to-builddri-plant-run-on-hydrogen-for-green-steel-production (accessed on 22 January 2021).

21. Nikolaidis, P.; Poullikkas, A. A comparative overview of hydrogen production processes. Renew. Sustain. Energy Rev. 2017, 67, 597-611. [CrossRef]

22. Buergler, T.; Prammer, J. Hydrogen steelmaking: Technology options and R\&D projects. BHM Berg Hüttenmännische Mon. 2019, $164,447-451$.

23. Matute, G.; Yusta, J.; Beyza, J.; Correas, L. Multi-state techno-economic model for optimal dispatch of grid connected hydrogen electrolysis systems operating under dynamic conditions. Int. J. Hydrogen Energy 2021, 46, 1449-1460. [CrossRef]

24. Kruck, O.; Crotogino, F.; Prelicz, R.; Rudolph, T. Overview on all known underground storage technologies for hydrogen. In HyUnder (2013 August) Delivery; Springer: Berlin, Germany, 2013; Volume 3.

25. Caglayan, D.G.; Weber, N.; Heinrichs, H.U.; Linßen, J.; Robinius, M.; Kukla, P.A.; Stolten, D. Technical potential of salt caverns for hydrogen storage in Europe. Int. J. Hydrogen Energy 2020, 45, 6793-6805. [CrossRef]

26. Gabrielli, P.; Poluzzi, A.; Kramer, G.J.; Spiers, C.; Mazzotti, M.; Gazzani, M. Seasonal energy storage for zero-emissions multienergy systems via underground hydrogen storage. Renew. Sustain. Energy Rev. 2020, 121, 109629. [CrossRef]

27. Böttcher, N.; Görke, U.-J.; Kolditz, O.; Nagel, T. Thermo-mechanical investigation of salt caverns for short-term hydrogen storage. Environ. Earth Sci. 2017, 76, 98. [CrossRef]

28. Johansson, F.; Spross, J.; Damasceno, D.; Johansson, J.; Stille, H. Investigation of Research Needs Regarding the Storage of Hydrogen Gas in Lined Rock Caverns: Prestudy for Work Package 2.3 in HYBRIT Research Program 1; KTH Royal Institute of Technology: Stockholm, Sweden, 2018.

29. Sofregaz, U.; Gustafsväg, C. Commercial Potential of Natural Gas Storage in Lined Rock Caverns (LRC); US Department of Energy: Washington, DC, USA, 1999.

30. Tengborg, P.; Johansson, J.; Durup, G. Storage of highly compressed gases in underground lined rock caverns-more than 10 years of experience. In Proceedings of the World Tunnel Congress 2014-Tunnels for a Better Life, Iguassu Falls, Brazil, 9-15 May 2014.

31. Laban, M. Hydrogen Storage in Salt Caverns: Chemical Modelling and Analysis of Large-Scale Hydrogen Storage in Underground Salt Caverns; Delft University of Technology: Delft, The Netherlands, 2020. 
32. Davies, J.; Dolci, F.; Klassek-Bajorek, D.; Ortiz Cebolla, R.; Weidner, E. Current status of Chemical Energy Storage Technologies; Publications Office of the European Union: Luxembourg, 2020.

33. Andersson, J.; Grönkvist, S. Large-scale storage of hydrogen. Int. J. Hydrogen Energy 2019, 44, 11901-11919. [CrossRef]

34. Smith, A.; Klosek, J. A review of air separation technologies and their integration with energy conversion processes. Fuel Process. Technol. 2001, 70, 115-134. [CrossRef]

35. Bos, M.J.; Kersten, S.R.A.; Brilman, D.W.F. Wind power to methanol: Renewable methanol production using electricity, electrolysis of water and $\mathrm{CO}_{2}$ air capture. Appl. Energy 2020, 264, 114672. [CrossRef]

36. Keith, D.W.; Holmes, G.; St. Angelo, D.; Heidel, K. A Process for Capturing $\mathrm{CO}_{2}$ from the Atmosphere. Joule 2018, 2, 1573-1594. [CrossRef]

37. Andersson, J.; Krüger, A.; Grönkvist, S. Methanol as a carrier of hydrogen and carbon in fossil-free production of direct reduced iron. Energy Convers. Manag. X 2020, 7, 100051. [CrossRef]

38. Robinson, R.; Brabie, L.; Pettersson, M.; Amovic, M.; Ljunggren, R. An Empirical Comparative Study of Renewable Biochar and Fossil Carbon as Carburizer in Steelmaking. ISIJ Int. 2020. ISIJINT-2020-2135. [CrossRef]

39. Echterhof, T. Review on the Use of Alternative Carbon Sources in EAF Steelmaking. Metals 2021, 11, 222. [CrossRef]

40. Eggemann, L.; Escobar, N.; Peters, R.; Burauel, P.; Stolten, D. Life cycle assessment of a small-scale methanol production system: A Power-to-Fuel strategy for biogas plants. J. Clean. Prod. 2020, 271, 122476. [CrossRef]

41. Buttler, A.; Spliethoff, H. Current status of water electrolysis for energy storage, grid balancing and sector coupling via power-togas and power-to-liquids: A review. Renew. Sustain. Energy Rev. 2018, 82, 2440-2454. [CrossRef]

42. Bergins, C.; Buddenberg, T.; Koytsoumpa, E.-I.; Duarte, M.J.; Kakaras, E.; Schmidt, S.; Deierling, A. A Technology Review and Cost Analysis of the Production of Low Carbon Methanol and Following Methanol to Gasoline Process. In Zukünftige Kraftstoffe; Springer: Berlin/Heidelberg, Germany, 2019; pp. 433-463.

43. Arpagaus, C.; Bless, F.; Uhlmann, M.; Schiffmann, J.; Bertsch, S.S. High temperature heat pumps: Market overview, state of the art, research status, refrigerants, and application potentials. Energy 2018, 152, 985-1010. [CrossRef]

44. Wismann, S.T.; Engbæk, J.S.; Vendelbo, S.B.; Bendixen, F.B.; Eriksen, W.L.; Aasberg-Petersen, K.; Frandsen, C.; Chorkendorff, I.; Mortensen, P.M. Electrified methane reforming: A compact approach to greener industrial hydrogen production. Science 2019, 364, 756-759. [CrossRef]

45. Rostrup-Nielsen, J.; Hansen, J.B. Steam reforming for fuel cells. In Fuel Cells: Technologies for Fuel Processing; Elsevier: Amsterdam, The Netherlands, 2011; pp. 49-71.

46. Voldsund, M.; Jordal, K.; Anantharaman, R. Hydrogen production with $\mathrm{CO}_{2}$ capture. Int. J. Hydrogen Energy 2016, 41, 4969-4992. [CrossRef]

47. Mortensen, P.M.; Østberg, M.; Nielsen, P.E.H. A Process for Producing Hydrogen or Syngas by Methanol Cracking. U.S. Patent Application 16/087,943, 18 April 2019.

48. Friedmann, B.; FAN, Z.; Tang, K. Low-Carbon Heat Solutions for Heavy Industry: Sources, Options, and Costs Today; Columbia SIPA Center on Global Policy: New York, NY, USA, 2019.

49. Energimyndigheten. Trädbränsle- och Torvpriser. 2019. Available online: https://www.energimyndigheten.se/statistik/denofficiella-statistiken/statistikprodukter/tradbransle--och-torvpriser/?currentTab=2\#mainheading (accessed on 2 March 2021).

50. Schaub, T. $\mathrm{CO}_{2}$-based hydrogen storage: $\mathrm{CO}_{2}$ hydrogenation to formic acid, formaldehyde and methanol. Phys. Sci. Rev. 2018, 3 . [CrossRef]

51. Van Putten, R.; Wissink, T.; Swinkels, T.; Pidko, E.A. Fuelling the hydrogen economy: Scale-up of an integrated formic acid-topower system. Int. J. Hydrogen Energy 2019, 44, 28533-28541. [CrossRef]

52. Bulushev, D.A.; Ross, J.R. Heterogeneous catalysts for hydrogenation of $\mathrm{CO}_{2}$ and bicarbonates to formic acid and formates. Catal Rev. 2018, 60, 566-593. [CrossRef]

53. Goeppert, A.; Czaun, M.; Jones, J.-P.; Prakash, G.S.; Olah, G.A. Recycling of carbon dioxide to methanol and derived productsclosing the loop. Chem. Soc. Rev. 2014, 43, 7995-8048. [CrossRef]

54. Marlin, D.S.; Sarron, E.; Sigurbjörnsson, Ó. Process Advantages of Direct $\mathrm{CO}_{2}$ to Methanol Synthesis. Front. Chem. 2018, 6, 446. [CrossRef] [PubMed]

55. Nyári, J.; Magdeldin, M.; Larmi, M.; Järvinen, M.; Santasalo-Aarnio, A. Techno-economic barriers of an industrial-scale methanol CCU-plant. J. $\mathrm{CO}_{2}$ Util. 2020, 39, 101166. [CrossRef]

56. Dieterich, V.; Buttler, A.; Hanel, A.; Spliethoff, H.; Fendt, S. Power-to-liquid via synthesis of methanol, DME or Fischer-Tropschfuels: A review. Energy Environ. Sci. 2020, 13, 3207-3252. [CrossRef]

57. Perez-Fortes, M.; Schoneberger, J.C.; Boulamanti, A.; Tzimas, E. Methanol synthesis using captured $\mathrm{CO}_{2}$ as raw material: Techno-economic and environmental assessment. Appl. Energy 2016, 161, 718-732. [CrossRef]

58. Tenhumberg, N.; Büker, K. Ecological and Economic Evaluation of Hydrogen Production by Different Water Electrolysis Technologies. Chem. Ing. Tech. 2020, 92, 1586-1595. [CrossRef]

59. Schittkowski, J.; Ruland, H.; Laudenschleger, D.; Girod, K.; Kähler, K.; Kaluza, S.; Muhler, M.; Schlögl, R. Methanol Synthesis from Steel Mill Exhaust Gases: Challenges for the Industrial $\mathrm{Cu} / \mathrm{ZnO} / \mathrm{Al}_{2} \mathrm{O}_{3}$ Catalyst. Chem. Ing. Tech. 2018, 90, 1419-1429. [CrossRef]

60. Ruland, H.; Song, H.; Laudenschleger, D.; Stürmer, S.; Schmidt, S.; He, J.; Kähler, K.; Muhler, M.; Schlögl, R. CO $\mathrm{CO}_{2}$ hydrogenation with $\mathrm{Cu} / \mathrm{ZnO} / \mathrm{Al}_{2} \mathrm{O}_{3}$ : A benchmark study. ChemCatChem 2020, 12, 3216-3222. [CrossRef] 


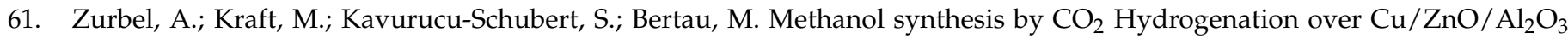
catalysts under fluctuating conditions. Chem. Ing. Tech. 2018, 90, 721-724. [CrossRef]

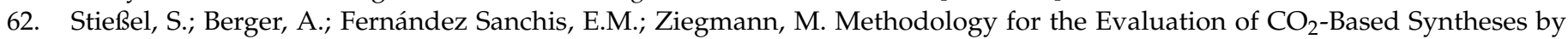
Coupling Steel Industry with Chemical Industry. Chem. Ing. Tech. 2018, 90, 1392-1408. [CrossRef]

63. Schweitzer, C. Small scale Methanol Plants: A chance for re-industrialisation. In Proceedings of the International Methanol Conference, Copenhagen, Demark, 8-10 May 2017.

64. Klankermayer, J.; Wesselbaum, S.; Beydoun, K.; Leitner, W. Selective Catalytic Synthesis Using the Combination of Carbon Dioxide and Hydrogen: Catalytic Chess at the Interface of Energy and Chemistry. Angew. Chem. Int. Ed. 2016, 55, 7296-7343. [CrossRef]

65. Szima, S.; Cormos, C.-C. Improving methanol synthesis from carbon-free $\mathrm{H}_{2}$ and captured $\mathrm{CO}_{2}$ : A techno-economic and environmental evaluation. J. $\mathrm{CO}_{2}$ Util. 2018, 24, 555-563. [CrossRef]

66. Frei, M.S.; Mondelli, C.; Short, M.I.; Pérez-Ramírez, J. Methanol as a Hydrogen Carrier: Kinetic and Thermodynamic Drivers for its $\mathrm{CO}_{2}$-Based Synthesis and Reforming over Heterogeneous Catalysts. ChemSusChem 2020, 13, 6330-6337. [PubMed]

67. Palo, D.R.; Dagle, R.A.; Holladay, J.D. Methanol steam reforming for hydrogen production. Chem. Rev. 2007, 107, 3992-4021. [CrossRef]

68. Behrens, M.; Armbrüster, M. Methanol Steam Reforming. In Catalysis for Alternative Energy Generation; Guczi, L., Erdôhelyi, A., Eds.; Springer: New York, NY, USA, 2012; pp. 175-235. [CrossRef]

69. Agrell, J.; Lindstrom, B.; Pettersson, L.J.; Jaras, S.G. Catalytic hydrogen generation from methanol. Catalysis 2002, 16, 1-2.

70. Agrell, J.; Birgersson, H.; Boutonnet, M. Steam reforming of methanol over a $\mathrm{Cu} / \mathrm{ZnO} / \mathrm{Al}_{2} \mathrm{O}_{3}$ catalyst: A kinetic analysis and strategies for suppression of CO formation. J. Power Sources 2002, 106, 249-257. [CrossRef]

71. Biedermann, P.; Grube, T.; Höhlein, B. Methanol as an Energy Carrier; Forschungszentrum Jülich: Jülich, Germany, 2006.

72. Stoll, R.; Von Linde, F. Hydrogen-what are the costs. Hydrocarb. Process 2000, 79, $42-46$.

73. Neumann, P.; von Linde, F. Options for economical supply of hydrogen. Metall. Plant Technol. Int. 2003, 2, 72-75.

74. Haid, J.; Koss, U. Lurgi's Mega-Methanol technology opens the door for a new era in down-stream applications. In Studies in Surface Science and Catalysis; Elsevier: Amsterdam, The Netherlands, 2001; Volume 136, pp. 399-404.

75. Grubel, K.; Jeong, H.; Yoon, C.W.; Autrey, T. Challenges and opportunities for using formate to store, transport, and use hydrogen. J. Energy Chem. 2020, 41, 216-224. [CrossRef]

76. Müller, K.; Brooks, K.; Autrey, T. Hydrogen Storage in Formic Acid: A Comparison of Process Options. Energy Fuels 2017, 31, 12603-12611. [CrossRef]

77. Schaub, T.; Paciello, R.A. A process for the synthesis of formic acid by $\mathrm{CO}_{2}$ hydrogenation: Thermodynamic aspects and the role of CO. Angew. Chem. Int. Ed. 2011, 50, 7278-7282. [CrossRef] [PubMed]

78. Kim, D.; Han, J. Comprehensive analysis of two catalytic processes to produce formic acid from carbon dioxide. Appl. Energy 2020, 264, 114711. [CrossRef]

79. Perez-Fortes, M.; Schoneberger, J.C.; Boulamanti, A.; Harrison, G.; Tzimas, E. Formic acid synthesis using $\mathrm{CO}_{2}$ as raw material: Techno-economic and environmental evaluation and market potential. Int. J. Hydrogen Energy 2016, 41, 16444-16462. [CrossRef]

80. Van der Burg, L.; Reijerkerk, J. HyChain 1, 2 \& 3: Energy Carriers and Hydrogen Supply Chain: A Management Summary; Institute for Sustainable Process Technology (ISPT): Amersfoort, The Netherlands, 2019.

81. Hwang, Y.J.; Kwon, Y.; Kim, Y.; Sohn, H.; Nam, S.W.; Kim, J.; Autrey, T.S.; Yoon, C.W.; Jo, Y.S.; Jeong, H. Development of an autothermal formate-based hydrogen generator: From optimization of formate dehydrogenation conditions to thermal integration with Fuel Cells. ACS Sustain. Chem. Eng. 2020, 8, 9846-9856. [CrossRef]

82. Müller, K.; Brooks, K.; Autrey, T. Releasing Hydrogen at High Pressures from Liquid Carriers: Aspects for the $\mathrm{H}_{2}$ Delivery to Fueling Stations. Energy Fuels 2018, 32, 10008-10015. [CrossRef]

83. Stathi, P.; Solakidou, M.; Louloudi, M.; Deligiannakis, Y. From Homogeneous to Heterogenized Molecular Catalysts for $\mathrm{H}_{2}$ Production by Formic Acid Dehydrogenation: Mechanistic Aspects, Role of Additives, and Co-Catalysts. Energies 2020, 13, 733. [CrossRef]

84. Theodorakopoulos, M.; Solakidou, M.; Deligiannakis, Y.; Louloudi, M. A Use-Store-Reuse (USR) Concept in Catalytic HCOOH Dehydrogenation: Case-Study of a Ru-Based Catalytic System for Long-Term USR under Ambient O2. Energies 2021, 14, 481. [CrossRef]

85. Sun, R.; Liao, Y.; Bai, S.; Zheng, M.; Zhou, C.; Zhang, T.; Sels, B. Heterogeneous catalysts for $\mathrm{CO}_{2}$ hydrogenation to formic acid/formate: From nanoscale to single atom. Energy Environ. Sci. 2021. [CrossRef]

86. Aziz, M.; Wijayanta, A.T.; Nandiyanto, A.B.D. Ammonia as Effective Hydrogen Storage: A Review on Production, Storage and Utilization. Energies 2020, 13, 3062. [CrossRef]

87. Nørskov, J.; Chen, J.; Miranda, R.; Fitzsimmons, T.; Stack, R. Sustainable Ammonia Synthesis—Exploring the Scientific Challenges Associated with Discovering Alternative, Sustainable Processes for Ammonia Production; US DOE Office of Science: Washington, DC, USA, 2016.

88. Smith, C.; Hill, A.K.; Torrente-Murciano, L. Current and future role of Haber-Bosch ammonia in a carbon-free energy landscape. Energy Environ. Sci. 2020, 13, 331-344. [CrossRef]

89. Liu, X.; Elgowainy, A.; Wang, M. Life cycle energy use and greenhouse gas emissions of ammonia production from renewable resources and industrial by-products. Green Chem. 2020, 22, 5751-5761. [CrossRef] 
90. Lin, B.; Wiesner, T.; Malmali, M. Performance of a small-scale Haber process: A techno-economic analysis. ACS Sustain. Chem. Eng. 2020, 8, 15517-15531. [CrossRef]

91. Hank, C.; Sternberg, A.; Köppel, N.; Holst, M.; Smolinka, T.; Schaadt, A.; Hebling, C.; Henning, H.-M. Energy efficiency and economic assessment of imported energy carriers based on renewable electricity. Sustain. Energy Fuels 2020, 4, $2256-2273$. [CrossRef]

92. Palys, M.J.; Daoutidis, P. Using hydrogen and ammonia for renewable energy storage: A geographically comprehensive techno-economic study. Comput. Chem. Eng. 2020, 136, 106785. [CrossRef]

93. Wang, L.; Xia, M.; Wang, H.; Huang, K.; Qian, C.; Maravelias, C.T.; Ozin, G.A. Greening ammonia toward the solar ammonia refinery. Joule 2018, 2, 1055-1074. [CrossRef]

94. Aneke, M.; Wang, M. Potential for improving the energy efficiency of cryogenic air separation unit (ASU) using binary heat recovery cycles. Appl. Therm. Eng. 2015, 81, 223-231. [CrossRef]

95. Zhang, Z.; Liguori, S.; Fuerst, T.F.; Way, J.D.; Wolden, C.A. Efficient ammonia decomposition in a catalytic membrane reactor to enable hydrogen storage and utilization. ACS Sustain. Chem. Eng. 2019, 7, 5975-5985. [CrossRef]

96. Jackson, C.; Fothergill, K.; Gray, P.; Haroon, F.; Makhloufi, C.; Kezibri, N.; Davey, A.; Lhote, O.; Zarea, M.; Davenne, T.; et al. Ammonia to Green Hydrogen Project: Feasibility Study; Business, Energy and Industrial Strategy: London, UK, 2020.

97. Preuster, P.; Papp, C.; Wasserscheid, P. Liquid Organic Hydrogen Carriers (LOHCs): Toward a Hydrogen-free Hydrogen Economy. Acc. Chem. Res. 2017, 50, 74-85. [CrossRef]

98. Bulgarin, A.; Jorschick, H.; Preuster, P.; Bösmann, A.; Wasserscheid, P. Purity of hydrogen released from the Liquid Organic Hydrogen Carrier compound perhydro dibenzyltoluene by catalytic dehydrogenation. Int. J. Hydrogen Energy 2020, 45, 712-720. [CrossRef]

99. Aakko-Saksa, P.; Repo, T.; Hurskainen, M.; Kaisalo, N.; Tallgren, J.; Keskiväli, L.; Auvinen, S.; Braunschweiler, A.; Simell, P.; Reinikainen, M. Liquid Organic Hydrogen Carriers; VTT Technical Research Centre of Finland: Espoo, Finland, 2020.

100. Aakko-Saksa, P.T.; Cook, C.; Kiviaho, J.; Repo, T. Liquid organic hydrogen carriers for transportation and storing of renewable energy-Review and discussion. J. Power Sources 2018, 396, 803-823. [CrossRef]

101. Modisha, P.M.; Ouma, C.N.; Garidzirai, R.; Wasserscheid, P.; Bessarabov, D. The prospect of hydrogen storage using liquid organic hydrogen carriers. Energy Fuels 2019, 33, 2778-2796. [CrossRef]

102. Makepeace, J.W.; He, T.; Weidenthaler, C.; Jensen, T.R.; Chang, F.; Vegge, T.; Ngene, P.; Kojima, Y.; de Jongh, P.E.; Chen, P. Reversible ammonia-based and liquid organic hydrogen carriers for high-density hydrogen storage: Recent progress. Int. J. Hydrogen Energy 2019, 44, 7746-7767. [CrossRef]

103. Rao, P.C.; Yoon, M. Potential Liquid-Organic Hydrogen Carrier (LOHC) Systems: A Review on Recent Progress. Energies 2020, 13, 6040. [CrossRef]

104. Hurskainen, M. Liquid Organic Hydrogen Carriers (LOHC): Concept Evaluation and Techno-Economics; VTT Technical Research Centre of Finland: Espoo, Finland, 2019.

105. Jorschick, H.; Preuster, P.; Durr, S.; Seidel, A.; Muller, K.; Bosmann, A.; Wasserscheid, P. Hydrogen storage using a hot pressure swing reactor. Energy Environ. Sci. 2017, 10, 1652-1659. [CrossRef]

106. Fikrt, A.; Brehmer, R.; Milella, V.-O.; Müller, K.; Bösmann, A.; Preuster, P.; Alt, N.; Schlücker, E.; Wasserscheid, P.; Arlt, W. Dynamic power supply by hydrogen bound to a liquid organic hydrogen carrier. Appl. Energy 2017, 194, 1-8. [CrossRef]

107. Jorschick, H.; Bulgarin, A.; Alletsee, L.; Preuster, P.; Bösmann, A.; Wasserscheid, P. Charging a Liquid Organic Hydrogen Carrier with Wet Hydrogen from Electrolysis. ACS Sustain. Chem. Eng. 2019, 7, 4186-4194. [CrossRef]

108. Jorschick, H.; Vogl, M.; Preuster, P.; Bösmann, A.; Wasserscheid, P. Hydrogenation of liquid organic hydrogen carrier systems using multicomponent gas mixtures. Int. J. Hydrogen Energy 2019, 44, 31172-31182. [CrossRef]

109. Jorschick, H.; Dürr, S.; Preuster, P.; Bösmann, A.; Wasserscheid, P. Operational Stability of a LOHC-Based Hot Pressure Swing Reactor for Hydrogen Storage. Energy Technol. 2019, 7, 146-152. [CrossRef]

110. Hydrogenious.net. Hydrogenious LOHC Technologies GmbH. 2020. Available online: https://www.hydrogenious.net/index. php/en/hydrogen-2-2/ (accessed on 15 January 2020).

111. Proost, J. Critical assessment of the production scale required for fossil parity of green electrolytic hydrogen. Int. J. Hydrogen Energy 2020, 45, 17067-17075. [CrossRef]

112. Saba, S.M.; Müller, M.; Robinius, M.; Stolten, D. The investment costs of electrolysis-A comparison of cost studies from the past 30 years. Int. J. Hydrogen Energy 2018, 43, 1209-1223. [CrossRef]

113. Mayyas, A.T.; Ruth, M.F.; Pivovar, B.S.; Bender, G.; Wipke, K.B. Manufacturing Cost Analysis for Proton Exchange Membrane Water Electrolyzers; National Renewable Energy Laboratory (NREL): Golden, CO, USA, 2019.

114. Energy Sector Management Assistance Program. Green Hydrogen in Developing Countries; World Bank: Washington, DC, USA, 2020.

115. Reuß, M.; Grube, T.; Robinius, M.; Preuster, P.; Wasserscheid, P.; Stolten, D. Seasonal storage and alternative carriers: A flexible hydrogen supply chain model. Appl. Energy 2017, 200, 290-302. [CrossRef]

116. Bertau, M.; Wernicke, H.J.; Schmidt, F.; Standt, U.-D.; Seyfried, F.; Buchholz, S.; Busch, G.; Winterberg, M.; Reichelt, L.; Pätzold, C.; et al. Methanol Utilisation Technologies. In Methanol: The Basic Chemical and Energy Feedstock of the Future: Asinger's Vision Today; Bertau, M., Offermanns, H., Plass, L., Schmidt, F., Wernicke, H.-J., Eds.; Springer: Berlin/Heidelberg, Germany, 2014 ; pp. 327-601. [CrossRef] 
117. Towler, G.; Sinnott, R. Chemical Engineering Design: Principles, Practice and Economics of Plant and Process Design; Elsevier: Amsterdam, The Netherlands, 2012.

118. Drury, D.J. Formic acid. In Kirk-Othmer Encyclopedia of Chemical Technology; Wiley: Hoboken, NJ, USA, 2000.

119. Eypasch, M.; Schimpe, M.; Kanwar, A.; Hartmann, T.; Herzog, S.; Frank, T.; Hamacher, T. Model-based techno-economic evaluation of an electricity storage system based on Liquid Organic Hydrogen Carriers. Appl. Energy 2017, 185, 320-330. [CrossRef]

120. Tremel, A. Evaluation and Discussion. In Electricity-Based Fuels; Springer: Berlin/Heidelberg, Germany, 2018 ; pp. 75-83.

121. Fischer, K.L.; Freund, H. On the Optimal Design of Load Flexible Fixed Bed Reactors: Integration of Dynamics into the Design Problem. Chem. Eng. J. 2020, 124722. [CrossRef]

122. Nestler, F.; Krüger, M.; Full, J.; Hadrich, M.J.; White, R.J.; Schaadt, A. Methanol Synthesis-Industrial Challenges within a Changing Raw Material Landscape. Chem. Ing. Tech. 2019, 90, 1409-1418. [CrossRef]

123. Supp, E. Improved Methanol Process. Hydrocarb. Process 1981, 71-75.

124. Avgouropoulos, G.; Schlicker, S.; Schelhaas, K.P.; Papavasiliou, J.; Papadimitriou, K.D.; Theodorakopoulou, E.; Gourdoupi, N.; Machocki, A.; Ioannides, T.; Kallitsis, J.K.; et al. Performance evaluation of a proof-of-concept $70 \mathrm{~W}$ internal reforming methanol fuel cell system. J. Power Sources 2016, 307, 875-882. [CrossRef]

125. Edwards, N.; Ellis, S.R.; Frost, J.C.; Golunski, S.E.; van Keulen, A.N.; Lindewald, N.G.; Reinkingh, J.G. On-board hydrogen generation for transport applications: The HotSpot ${ }^{\mathrm{TM}}$ methanol processor. J. Power Sources 1998, 71, 123-128. [CrossRef]

126. Armijo, J.; Philibert, C. Flexible production of green hydrogen and ammonia from variable solar and wind energy: Case study of Chile and Argentina. Int. J. Hydrogen Energy 2020, 45, 1541-1558. [CrossRef]

127. Ostuni, R.; Zardi, F. Method for Load Regulation of an Ammonia Plant. U.S. Patent Application 13/626,316, 25 September 2012.

128. Cheema, I.I.; Krewer, U. Operating envelope of Haber-Bosch process design for power-to-ammonia. RSC Adv. 2018, 8, 34926-34936. [CrossRef]

129. Schulte Beerbühl, S.; Fröhling, M.; Schultmann, F. Combined scheduling and capacity planning of electricity-based ammonia production to integrate renewable energies. Eur. J. Oper. Res. 2015, 241, 851-862. [CrossRef]

130. Hawkins, S.; Joffe, D. Technological Characterisation of Hydrogen Storage and Distribution Technologies; Policy Studies Institute: London, UK, 2006.

131. Hydrogenious LOHC Technologies GmbH. The StorageUNIT. 2020. Available online: https:/ /www.hydrogenious.net/index. php/en/products/thestorageunit/\#anchor_storageunit_sseries (accessed on 2 November 2020). 